\title{
Loss of NSCL-2 in Gonadotropin Releasing Hormone Neurons Leads to Reduction of Pro-Opiomelanocortin Neurons in Specific Hypothalamic Nuclei and Causes Visceral Obesity
}

\author{
Thomas Schmid, ${ }^{1}$ Stefan Günther, ${ }^{1}$ Luca Mendler, ${ }^{2}$ and Thomas Braun ${ }^{1}$ \\ ${ }^{1}$ Max Planck Institute for Heart and Lung Research, D-61231 Bad Nauheim, Germany, and 2Institute of Biochemistry, Faculty of General Medicine, \\ University of Szeged, H-6720 Szeged, Hungary
}

Regulation of sexual reproduction and energy homeostasis are closely interconnected, but only few efforts were made to explore the impact of gonadotropic neurons on metabolic processes. We have used Nscl-2 mutant mice suffering from adult onset of obesity and hypogonadotropic hypogonadism to study effects of gonadotropin releasing hormone $(\mathrm{GnRH})$ neurons on neuronal circuits controlling energy balance. Inactivation of $\mathrm{Nscl}-2$ in $\mathrm{GnRH}$ neurons but not in pro-opiomelanocortin (POMC) neurons reduced POMC neurons and increased visceral fat mass, suggesting a critical role of $\mathrm{GnRH}$ cells in the regulation of POMC neurons. In contrast, absence of POMC processing in the majority of $\mathrm{Nscl}$-2-deficient POMC neurons had no effect on energy homeostasis. Finally, we investigated the cellular basis of the reduction of GnRH neurons in NSCL-2 mutants using a lineage tracing approach. We found that loss of Nscl-2 results in aberrant migration of $\mathrm{GnRH}$ neurons in $\mathrm{Nscl}-2$ mutant mice causing a lineage switch of ectopically located GnRH neurons.

\section{Introduction}

Onset of puberty is controlled by awakening of gonadotropin releasing hormone $(\mathrm{GnRH})$ neurons, which start to release $\mathrm{GnRH}$ in a pulsatile manner, leading to activation of GnRHdependent hypothalamic-pituitary-gonadal axis, gametogenesis, and increase in gonadal steroid production (Sisk and Foster, 2004). Absence of GnRH neurons or mutations of the GnRH gene results in hypogonadotropic hypogonadism. Multiple signals are involved in the reemergence of GnRH secretion at puberty. One of the most important permissive signals is acquisition of sufficient body energy reserves, which is sensed, among others, by two key metabolic hormones, leptin and ghrelin, illustrating the impact of metabolic signals on the onset of puberty (Roa et al., 2010).

The close relationship of regulation of sexual reproduction and energy homeostasis is also evident in the phenotype of $\mathrm{Nscl}-2$ mutant mice. During development, Nscl-2 (also known as Nhlh2 for nescient helix-loop-helix 2) is expressed in GnRH neurons as

\footnotetext{
Received Nov. 14, 2012; revised May 15, 2013; accepted May 18, 2013.

Author contributions: T.S., S.G., and T.B. designed research; T.S., S.G., and L.M. performed research; T.S. and S.G. analyzed data; T.S. and T.B. wrote the paper.

This work was funded by the Max Planck Society and the Excellence Initiative "Cardiopulmonary System," the University of Giessen-Marburg Lung Centre, and the Cell and Gene Therapy Centre, supported by the Minister for Higher Education, Research, and the Arts. We express our gratitude to the colleagues who shared mice (Catherine Dulac for GnRH-Cre, Malcom Low for POMC-EGFP, and Brad Lowell for POMC-Cre) and antibodies (Robert Benoit for anti-GnRH, Henryk Urbanski for anti-GnRH, and A. F. Parlow for anti-ACTH) to enable this study. The help of Marianne Ploch with genotyping is greatly acknowledged.

The authors declare no competing financial interests.

Correspondence should be addressed to Thomas Braun, Max Planck Institute for Heart and Lung Research, Ludwigstrasse 43, D-61231 Bad Nauheim, Germany. E-mail: thomas.braun@mpi-bn.mpg.de.

DOI:10.1523/JNEUROSCI.5287-12.2013

Copyright $\odot 2013$ the authors $\quad 0270-6474 / 13 / 3310459-12 \$ 15.00 / 0$
}

well as in multiple areas of the CNS and PNS. In adult mice, NSCL-2 is found in the paraventricular (PVN) and arcuate (Arc) nuclei of the hypothalamus (Krüger et al., 2004), in which its expression is stimulated by food intake and leptin injection (Vella et al., 2007). Nscl-2 mutant mice show an adult onset of obesity with increased visceral fat depots and reduced fertility (Good et al., 1997; Krüger et al., 2004). So far, it was not clear whether loss of NSCL-2 expression in GnRH neurons is responsible for reduction of GnRH neurons and reduced fertility of $\mathrm{Nscl}-2$ mutants, although it has been demonstrated that NSCL-2 and its close relative, NSCL-1, are concomitantly involved in the control of differentiation and migration of GnRH neurons probably via regulation of necdin expression (Krüger et al., 2004). In response to leptin signaling, NSCL-2 regulates expression of the prohormone convertase $1 / 3(\mathrm{PC} 1 / 3)$ in hypothalamic neurons (Fox and Good, 2008), which is required for proteolytic processing of pro-opiomelanocortin (POMC) into ACTH and $\alpha$-melanocytestimulating hormone ( $\alpha$-MSH), $\alpha$-MSH restricts food intake by signaling via melanocortin-4 receptor (MC4-R) and mediates increased energy expenditure (Elmquist, 2001). Conversely, $\alpha$-MSH also plays a role in the reproductive system (Crown et al., 2007). Hence, NSCL-2-mediated generation of $\alpha$-MSH might represent a link between energy homeostasis and fertility (Jing et al., 2004).

The importance of metabolic control of puberty onset and sexual maturation is well investigated. In contrast, very little attention has been paid to a possible signaling modality from cells controlling reproductive maturation (i.e., the $\mathrm{GnRH}$ system) to cells that govern feeding and energy expenditure. Only a recent report demonstrated a direct contact of GnRH fibers to POMC 
neurons in the Arc (Sotonyi et al., 2010). Here, we explored processes mediating effects of the reproductive system on energy homeostasis by targeted inactivation of the $\mathrm{Nscl}-2$ gene in distinct cell populations of female mice.

\section{Materials and Methods}

Mice. Generation and genotyping of NSCL-2 ${ }^{-1-}$ (Krüger et al., 2004), POMC-GFP (Cowley et al., 2001), Deleter-Cre (Schwenk et al., 1995), GnRH-Cre (Yoon et al., 2005), and POMC-Cre (Balthasar et al., 2004) strains have been described previously. To generate a conditionally inactive $\mathrm{Nscl}-2$ allele, the genomic sequence of $\mathrm{Nscl}-2$ derived from the 129S7AB2.2 genomic BAC clone (bMQ-306K18) was inserted via gap repair into the pKOIIV2 targeting vector and modified by insertion of loxP sites. All strains were maintained on a C57BL/6 genetic background after backcrossing for at least three generations.

Experimental mice were compared with wild-type littermate controls or mice carrying a single floxed allele $\left(\mathrm{NSCL}-2^{\text {loxP/+ }}\right)$. Animals were derived from breeding between animals that were heterozygous and homozygous for the floxed $\mathrm{Nscl}-2$ gene and carried the respective Cre allele. In case of infertility, heterozygous animals were used. Mice were housed in groups of two to four at $25^{\circ} \mathrm{C}$ using a $12 \mathrm{~h}$ light/dark cycle and fed a standard pellet chow (Altromin) with water ad libitum. All animal experiments were done in accordance with the National Institutes of Health Guide for the Care and Use of Laboratory Animals (Publication 85-23, revised 1996) and according to the regulations issued by the Committee for Animal Rights Protection of the States of Hessen (Regional Government Office of Darmstadt) and Saxony-Anhalt. Animal experiments at the University of Szeged were approved by the local institutional animal care and use committee in accordance with the National Institutes of Health guidelines for animal care.

Reproductive and metabolic phenotyping. Reproductive success was determined by mating mutant mice in individually ventilated cages (IVCs) with wild-type control mice known to be fertile for at least 1 month or as long as a litter was generated. Female mice subjected to measurement of body fat were kept in small groups together with control female mice in IVCs and fed a standard pellet chow (Altromin) and water ad libitum. No contact with males was allowed. Energy expenditure and food intake was determined using the PhenoMaster System (TSE Systems) by measuring water intake, food intake, and gas exchange $\left(\mathrm{O}_{2}\right.$ and $\left.\mathrm{CO}_{2}\right)$ as described previously (Jordan et al., 2011). Adult female mice were acclimated for $4 \mathrm{~d}$ in metabolic chambers before recordings ( $3 \mathrm{~d}$ ) were started. Leptin injections ( $150 \mu \mathrm{g} / \mathrm{kg}$ body weight in PBS) were given $10 \mathrm{~h}$ after onset of the light cycle at the time of lowest plasma leptin level (Arble et al., 2011). Mice were transcardially perfused with PBS, followed by $4 \%$ paraformaldehyde 30 min after the treatment.

Antibody and LacZ staining. For immunofluorescence, stainings were done using standard procedures. The following antibodies were used: anti- $\alpha$-MSH (catalog \#123811; Abcam); rabbit anti-c-Fos (catalog \#2c253; Santa Cruz Biotechnology); rabbit anti-GnRH (LR-5) (provided by Dr. Robert Benoit, McGill University, Montreal, Quebec, Canada); mouse anti-GnRH (HU) (provided by Dr. Henryk Urbanski, Oregon Health and Science University, Portland, OR); and rabbit anti-hACTH (provided by Dr. A. F. Parlow, Pituitary Hormones and Antisera Center, Harbor-University of California, Los Angeles Medical Center, Torrance, CA). The anti-hACTH antibody does not react against unprocessed POMC and shows no cross-reactivity against other pituitary hormones. LacZ staining of cryosections $(20-200 \mu \mathrm{m})$ was performed as described previously (Krüger et al., 2004). Statistical analysis was performed with Student's $t$ test. The level of significance was set at $p<0.05$. Data were presented as mean \pm SEM.

Western blot analysis. Western blot analyses were accomplished following standard procedures. Bound antibodies were visualized using the enhanced chemiluminescence system (ECL ${ }^{\star}$ Plus; GE Healthcare Pharmacia) as described previously (Jordan et al., 2011).

Serum estradiol enzymatic immunoassay. Mouse serum was collected by venipuncture of the caudal vena cava. Estradiol was measured according to the protocol of the manufacturer (Mouse/Rat Estradiol ELISA; Calbiotech) (Haisenleder et al., 2011).

\section{Results}

Constitutive loss of $\mathrm{Nscl}-2$ results in reduction of POMC-expressing cells in the medial preoptic area and the posterior hypothalamus

$\mathrm{Nscl}-2$ mutant mice suffer from adult onset of obesity. The finding that NSCL-2 is coexpressed with POMC in the Arc has raised the possibility that NSCL-2 directs development and/or maintenance of POMC neurons and thereby controls body weight. To determine more precisely the number of POMC-expressing neurons in Nscl-2 mutant mice, we took advantage of POMC-GFP mice, which express GFP under control of the POMC promoter (Cowley et al., 2001). Analysis of POMC-GFP/NSCL-2 ${ }^{-/-}$mice revealed a significant reduction of the number of POMCexpressing neurons in 15- to 21-week-old female Nscl-2 mutant mice in the medial preoptic area (MPO) (up to 50\%) and posterior hypothalamus (PH) (up to 60\%) (Fig. $1 \mathrm{~B}, \mathrm{C}$ ). Surprisingly, prepubertal NSCL-2 $2^{-/-}$female mice at 3 weeks (MPO, $185 \pm$ 15\%; Arc, $115 \pm 10 \%$; PH, $111 \pm 3 \%$ ) and 6 weeks (MPO, $193 \pm$ $16 \%$; Arc, $112 \pm 17 \%$; PH, $201 \pm 23 \%$ ) after birth showed a clear increase of POMC-expressing neurons in the MPO, Arc, and PH together with an ectopic localization of POMC-GFP-positive cells in the medial mammillary nucleus (MM) (Fig. 1A). The number of POMC-expressing neurons in Nscl-2 mutants declined only after puberty at 9 weeks after birth (MPO, $40 \pm 8 \%$; Arc, $82 \pm 8 \%$; PH, $50 \pm 19 \%$ ) (Fig. 1A), suggesting that the onset of puberty and associated regulatory circuits have an impact on the regulation of POMC expression. We also found a strong reduction of POMC-processing POMC neurons in the Arc as indicated by the absence of ACTH (Fig. 1), which is a product of POMC processing. No processing of POMC to ACTH was seen in POMC-expressing neurons located in the MPO and PH of control mice and $\mathrm{NSCL}-2^{-1-}$ mutant mice (and in a minority of POMC neurons in the Arc), indicating that these neurons do not signal via the classical cleavage products of POMC but probably by other means (Fig. $1 B-D$ ). Previously, it had been demonstrated that NSCL-2 controls processing of POMC to ACTH most likely by regulation of $\mathrm{PC} 1 / 3$, which cleaves POMC in hypothalamic POMC-expressing neurons (Jackson et al., 1997; Jing et al., 2004). Obviously, this regulatory mechanism is not active in a subpopulation of POMC neurons in the Arc that still expresses the POMC-GFP reporter (Fig. 1B,D).

To investigate whether POMC-expressing neurons in the Arc, compared with those in the MPO and $\mathrm{PH}$, would react differently to leptin signaling, we monitored expression of c-Fos in POMCexpressing neurons as an indirect marker of neuronal activity. The low basic c-Fos activity in POMC neurons of the Arc after $4 \mathrm{~h}$ of fasting increased strongly when animals were injected intraperitoneally with leptin (Fig. $1 E, F$ ). No differences in c-Fos activity were detected between POMC-expressing neurons of NSCL $-2^{+/-}$and NSCL-2 $2^{-/-}$littermates in the Arc. Surprisingly, we observed a decrease of c-Fos activity in POMC-expressing neurons located within the MPO and $\mathrm{PH}$, suggesting that POMC-expressing neurons located outside the Arc react differently to leptin stimulation and hence might fulfill a different functional role (Fig. 1E,F). Similar to the situation in the Arc, we did not find differences in c-Fos activity after leptin stimulation between NSCL-2 $2^{+/-}$and NSCL-2 $2^{-/-}$POMC-expressing neurons of the MPO and $\mathrm{PH}$ (Fig. $1 E$ ). Together, our results reveal that POMC-expressing neurons in the Arc react differently to leptin compared with those in the MPO and $\mathrm{PH}$ but that this differential response to leptin was not affected by the absence of NSCL-2 in remaining POMC-expressing neurons. 


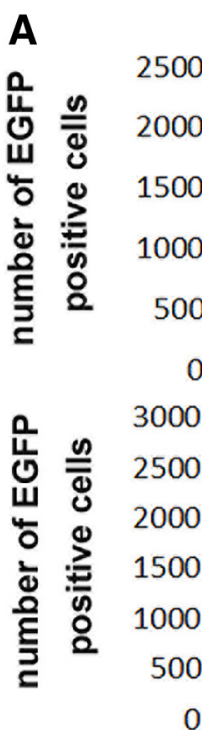

MPO

Arc

MM

PH
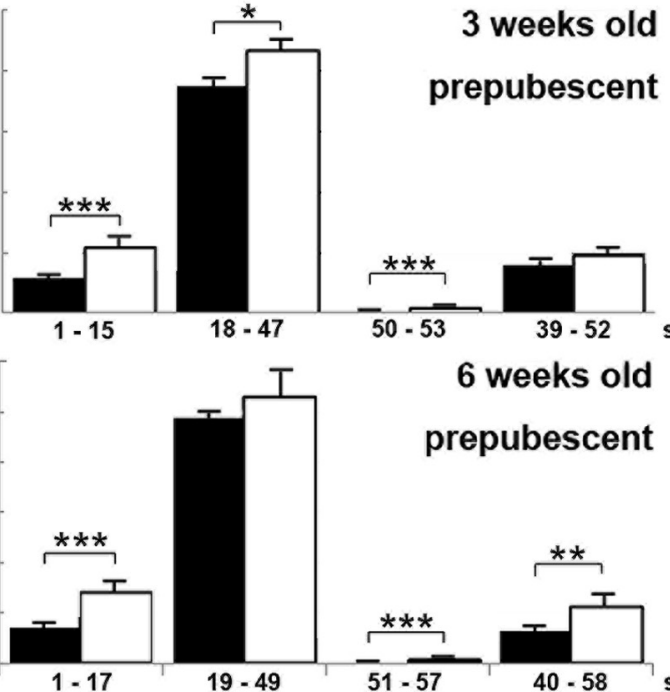

3 weeks old
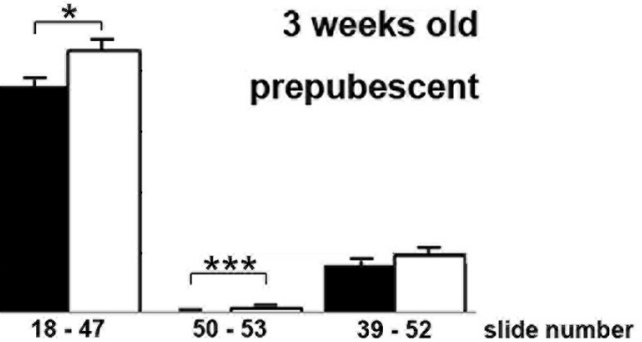

6 weeks old

prepubescent

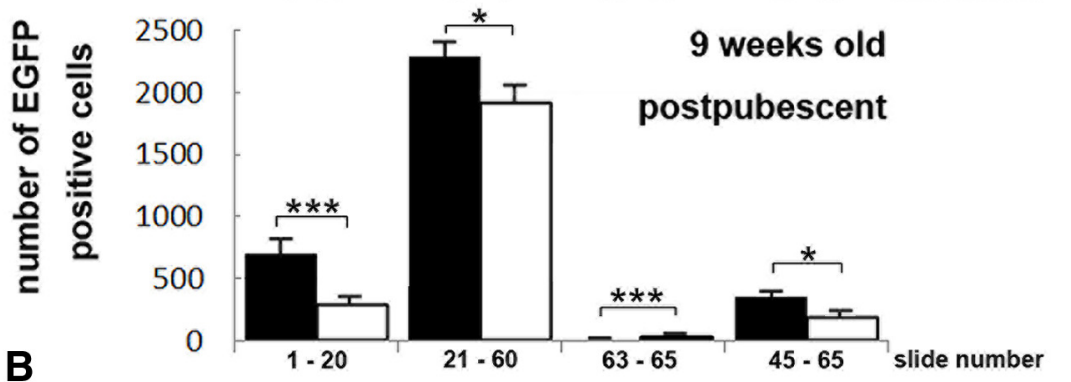

B

9 weeks old

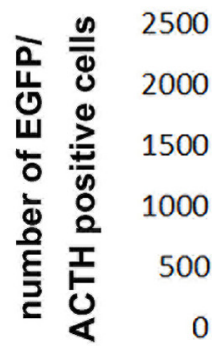

E
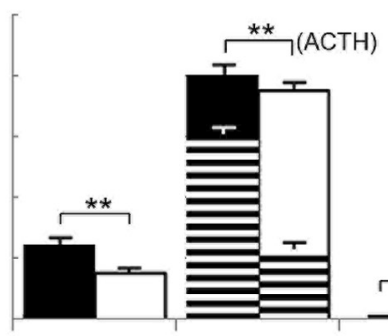

POMC EGFP/NSCL-2 $\square$ POMC EGFP/NSCL-2 $2^{\text {lacz/lacz }}$ 目 ACTH positive cells

MPO
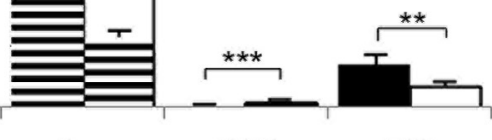

MM

$\mathrm{PH}$

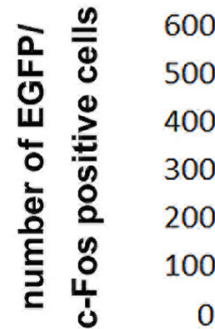

Arc

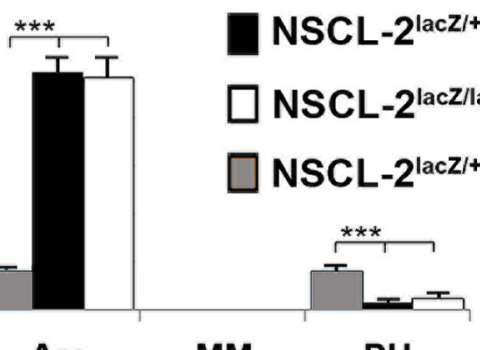

MPO

Arc

MM

PH

Figure 1. Reduction of POMC neurons in constitutive Nscl-2 mutants after puberty. $A$, Number of POMC-EGFP-positive neurons at different juvenile stages in POMC-EGFP/NSCL-2 ${ }^{+/-}(n=6$, black bars) and POMC-EGFP/NSCL-2 ${ }^{-1-}(n=6$, white bars) female mice. $B$, Number of POMC-GFP-positive (black and white bars) and ACTH-positive (striped bars) bars of adult (15-21 weeks old) POMC-EGFP/NSCL-2 $2^{+/-}$and POMC-EGFP/NSCL-2 $2^{-/-}$female mice. C, ACTH and GnRH staining of representative sections from the Arc and MPO of adult POMC-EGFP/NSCL-2 $2^{+/-}$and POMCEGFP/NSCL-2 ${ }^{-/-}$female mice. DMH, Dorsomedial nucleus hypothamamus. D, Double staining for ACTH (red) and POMC-EGFP (green). E, Number of POMC-GFP/c-Fos-positive cells in POMCEGFP/NSCL-2 $2^{+/}$mice without (gray bars) and after (black bars) leptin treatment and POMC-GFP/C-Fos-positive cells in POMC-EGFP/NSCL-2 ${ }^{-/-}$mice (white bars). $F$, Representative sections of the Arc of adult POMC-EGFP/NSCL-2 ${ }^{+/-}$female mice after c-Fos staining. Thickness of all sections, $50 \mu \mathrm{m} .{ }^{*} p<0.05 ;{ }^{* *} p<0.01 ;{ }^{* * *} p<0.001$.

Expression of NSCL-2 in hypothalamic POMC neurons controls processing of ACTH but not regulation of POMCs numbers and visceral fat mass accumulation

To investigate whether continuous presence of NSCL-2 is necessary for expression of $\mathrm{PC} 1 / 3$, required for processing of $\mathrm{POMC}$ in mature POMC-expressing neurons, we generated mice carrying a conditionally active $\mathrm{Nscl}-2$ allele (NSCL-2 $\left.2^{\text {loxP/loxP}}\right)$ by inserting loxP sites upstream and downstream of the main coding exon 3 of $\mathrm{Nscl}$-2, which contains the bHLH DNA-binding domain. We bred NSCL-2 ${ }^{\text {loxP/loxP }}$ mice with POMC-Cre mice (Balthasar et al., 
2004). This cross yielded POMC-Cre/ $N S C L-2^{\Delta l o x P / \Delta l o x P}$ mice that lack Nscl-2 in all POMC-expressing cells but retain $\mathrm{Nscl}-2$ expression in other cells, such as GnRH neurons. Immunohistochemical and Western blot analysis of these mice revealed a severe reduction of ACTH-positive and $\alpha$-MSH-positive neurons and fibers within the hypothalamus (Fig. $2 A$ ), which closely resembled the absence of ACTH staining in constitutive $\mathrm{Nscl}-2$ knock-out mice (Fig. 1C), corroborating previous results (Jing et al., 2004). However, a relatively small number of ACTH-positive neurons remained in the POMC-Crel NSCL-2 $2^{\Delta l o x P / \Delta l o x P}$ mice ( $\sim 500$ neurons) similar to the situation in constitutive $\mathrm{Nscl}-2$ mutants (Fig. $1 B$ ), again indicating that expression of $\mathrm{PC} 1 / 3$ does not depend on NSCL-2 in all neurons.

We next wanted to know whether the absence of $\mathrm{Nscl}-2$ in POMC neurons might affect the number of POMC-expressing neurons. Therefore, we crossed POMCCre/NSCL-2 $2^{\Delta l o x P / \Delta l o x P}$ mice with POMCGFP mice, which allowed a direct access to POMC-expressing cells (Cowley et al., 2001). Normal numbers of POMC-GFP neurons were identified in POMC-Crel NSCL-2 $2^{\Delta \operatorname{lox} P / \Delta \operatorname{lox} P}$ mice (MPO, $95 \pm 12 \%$; Arc, $96 \pm 5 \%$; PH, $103 \pm 3 \%$ ) compared with POMC-Cre/NSCL-2 $2^{\Delta l o x P /+}$ controls (Fig. $2 F$ ), indicating that expression of NSCL-2 in POMC neurons is dispensable for their formation and survival.

Interestingly, the normal number of POMC-expressing neurons in POMCCre/NSCL-2 $2^{\Delta l o x P / \Delta l o x P}$ mice corresponded to a normal weight curve and normal visceral $(111 \pm 35 \%)$ and subcutaneous fat depots compared with POMC-Crel NSCL-2 $2^{\Delta l o x P /+}$ and wild-type controls (Fig. $2 B, E$ ) despite the absence of proper POMC processing to $\alpha$-MSH and ACTH in most POMC neurons (Fig. 2). It was surprising to note that the failure to generate $\alpha-\mathrm{MSH}$ and ACTH in the majority of POMC neurons had no discernible effect under normal feeding conditions on body weight regulation and acquisition of visceral fat depots. We also analyzed the daily metabolism of POMC-Cre/NSCL- $2^{\Delta l o x P / \Delta l o x P}$ mice by indirect calorimetry and measurement of food and water intake. We were unable to find statistically significant differences in any of these parameters compared with wild-type control mice (data not shown).

In addition to anorexigenic POMC neurons, feeding and weight control is also affected by orexigenic NPY-AgRP neurons, which contact and regulate GnRH neurons via the NPY receptor $\mathrm{Y}_{5}$ (Li et al., 1999; Campbell et al., 2001). In addition, NPY-mediated activation of the $\mathrm{Y}_{5}$ receptor inhibits release of luteinizing hormone (LH) (Raposinho et al., 1999). Therefore, we wanted to know whether inactivation of Nscl-2 in NPY-AgRP neurons would recapitulate aspects of the obesity and infertility phenotype seen in constitutive
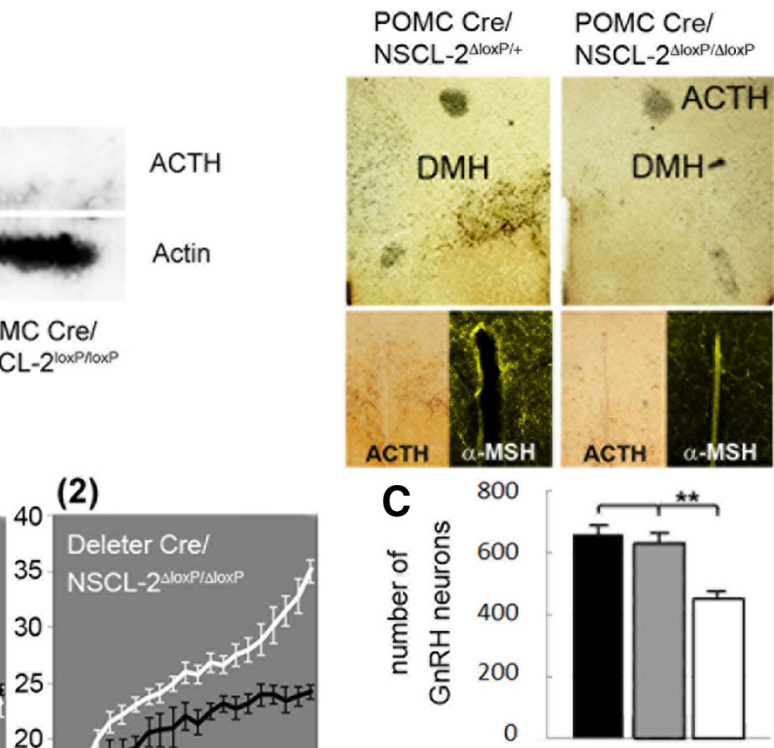

D
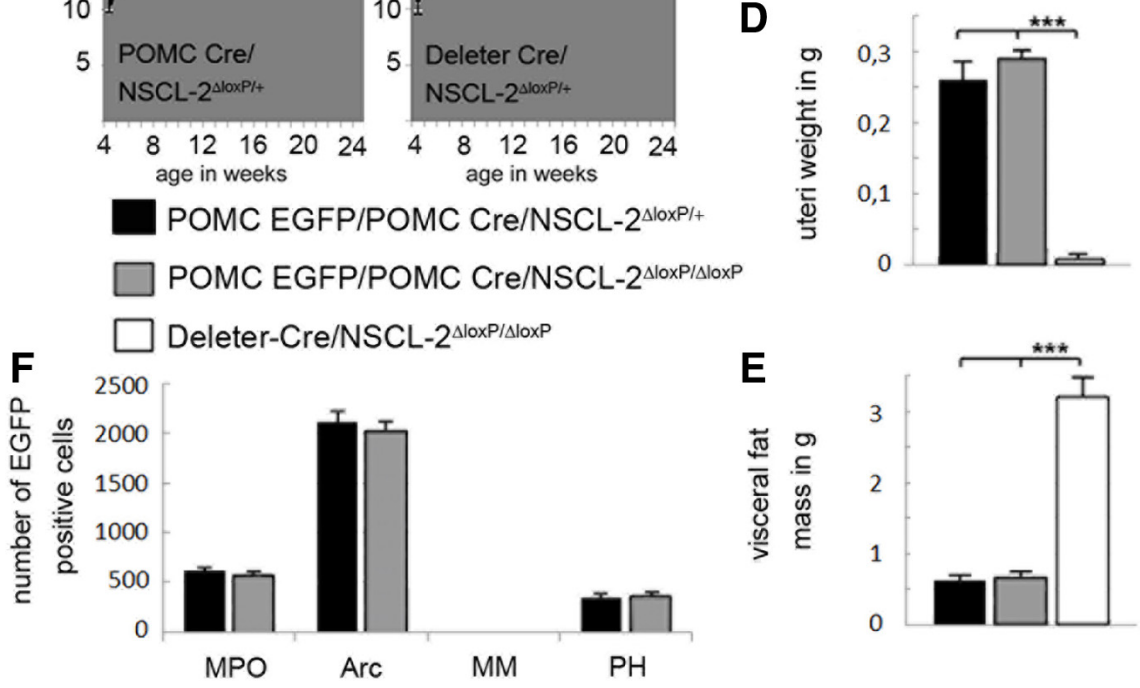

Figure 2. Inactivation of NsCl-2 in POMC neurons prevents processing of POMC and $\alpha$-MSH but does not cause obesity. $A$, Left, Western blot analysis of ACTH expression after selective inactivation of NsCl-2 in POMC neurons in POMC-Cre/NSCL-2 ${ }^{\Delta / \text { oxP/DloxP }}$ mice. Right, Immunostaining of sections through the dorsomedial nucleus hypothalamus (DMH) of POMC-Cre/NSCL-2 $2^{\Delta / \text { oxp/D/oxP }}$ mice compared with POMC-Cre/NSCL-2 ${ }^{\Delta / 0 x P /+}$ mice reveals reduced presence of ACTH (brown) and $\alpha$-MSH (green) fibers. Increased body weight $(\boldsymbol{B})$ and visceral fat mass (E) in Deleter-Cre/NSCL-2 ${ }^{\Delta / 0 \times P / \Delta l o x P}$ (white bar) but not in POMC-Cre/NSCL-2 ${ }^{\Delta / 0 \times P / \Delta / o x P}$ (gray bar in $\boldsymbol{E}$ ) mice. $\boldsymbol{D}$, Hypogonadism in Deleter-Cre/NSCL-2 ${ }^{\Delta / 0 x P / \Delta l o x P}$ (white bar) but not in POMC-Cre/NSCL-2 $2^{\Delta / \text { oxP/D/oxP }}$ mice (gray bar). C, F, Normal numbers of POMC and GnRH neurons in POMC-Cre/NSCL-2 ${ }^{\Delta / \text { oxP/D/oxP }}$ compared with POMC-Cre/NSCL-2 $2^{\Delta / \text { oxP/+ }}$ mice. Mice used for analysis were 5-8 months old. ${ }^{* *} p<0.01 ;{ }^{* * *} p<0.001$.

Nscl-2 mutants, in particular because NSCL-2 is strongly expressed in the Arc, in which NPY-AgRP pacemaker neurons are located (van den Top et al., 2004). Surprisingly, NPY-AgRP-Cre/NSCL$2^{\Delta l o x P / \Delta l o x P}$ mice (Kaelin et al., 2004) did not show any abnormalities in body weight regulation ( $96 \pm 7 \%$ ), visceral fat mass accumulation (84 $\pm 9 \%$ ), and hypogonadism (uteri weight, $115 \pm 5 \%$ ) compared with NSCL-2 $2^{\text {loxP/loxP }}$ and wild-type control animals. Similar results were obtained when analyzing Kisspeptin-Cre/NSCL-2 $2^{\Delta l o x P / \Delta l o x P}$ mice (Mayer et al., 2010) (body weight, $103 \pm 13 \%$; visceral fat mass, $113 \pm 6 \%$; uteri weight, $90 \pm 8 \%$ ). We concluded that loss of NSCL-2 expression in NPY-AgRP and Kisspeptin neurons is not relevant for adult onset of obesity and hypogonadism in $\mathrm{Nscl}-2$ mutants. 

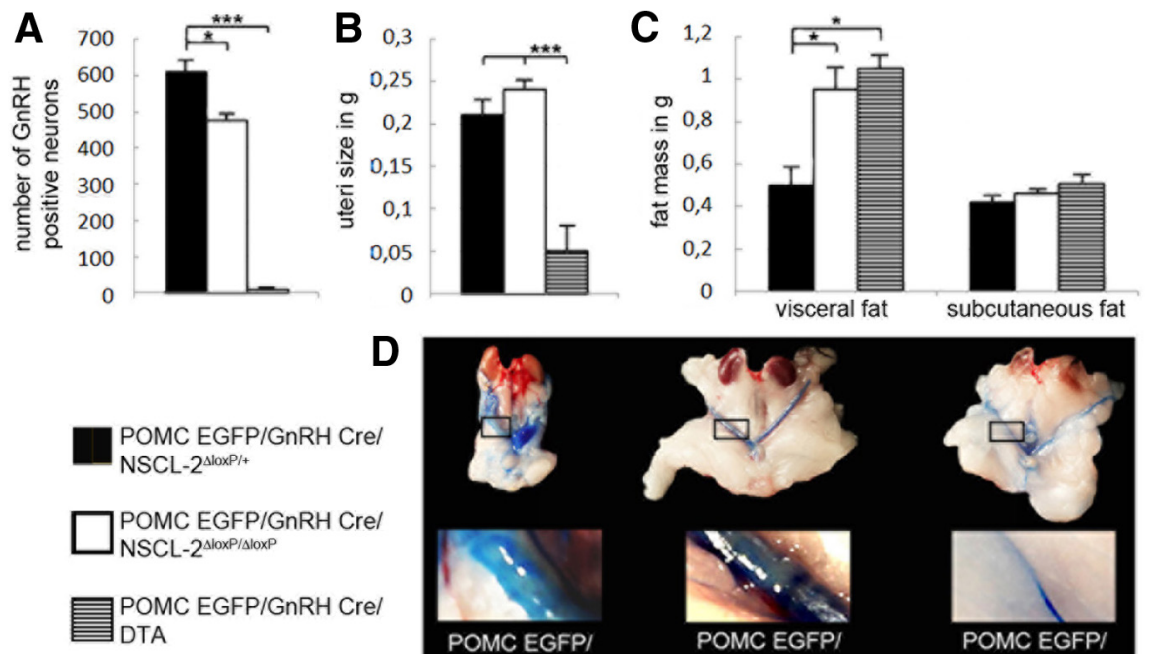

E
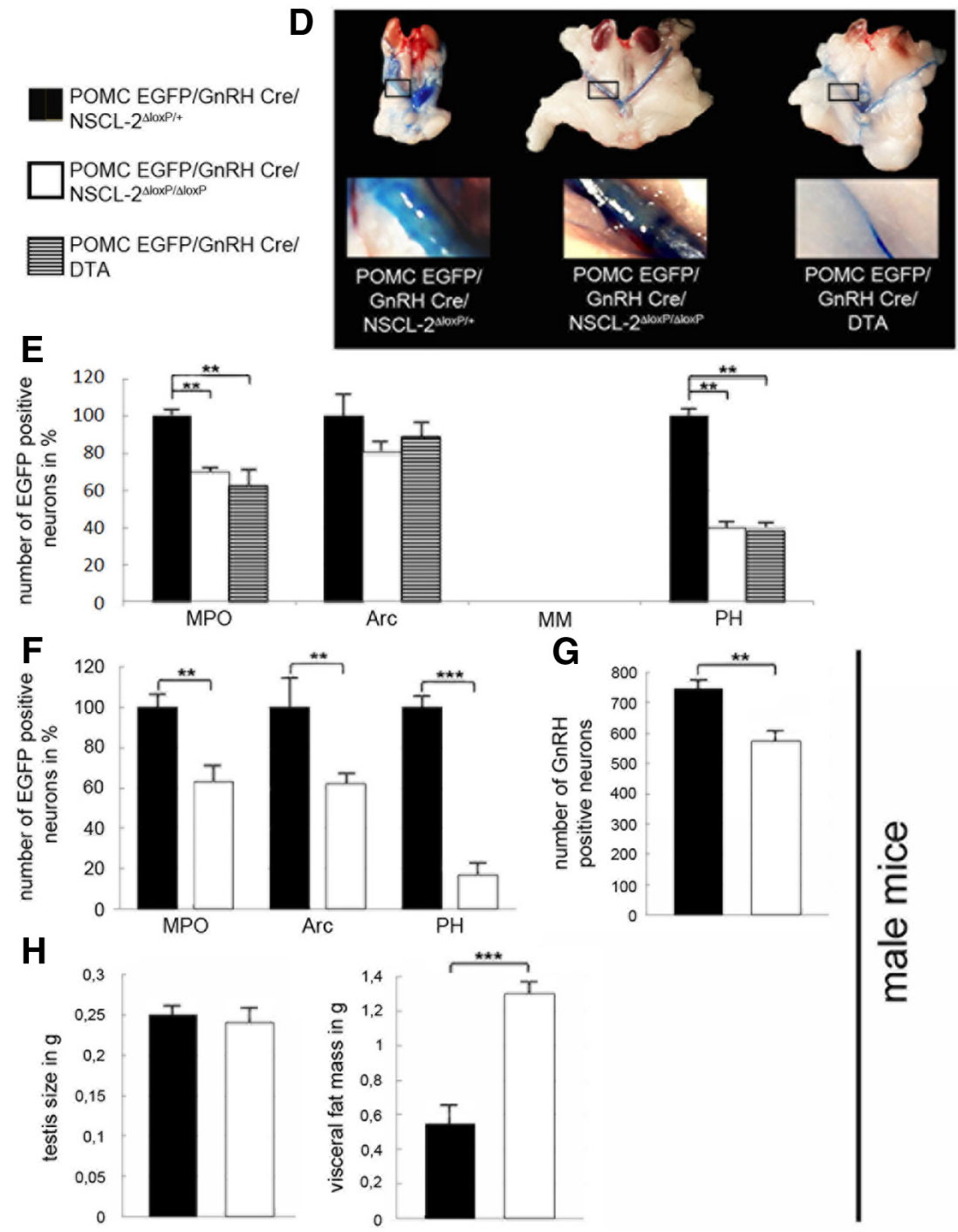

Figure 3. Reduction of POMC neurons after inactivation of $\mathrm{NsCl}-2$ in $\mathrm{GnRH}$ neurons or after ablation of $\mathrm{GnRH}$ neurons. $\boldsymbol{A}$, Reduction of GnRH neurons in female GnRH-Cre/NSCL-2 $2^{\Delta / 0 x P / \Delta / o x P}(n=8$, white bars) and virtually complete absence in GnRH-Cre/DTA female mice ( $n=4$, striped bars) compared with GnRH-Cre/NSCL-2 $2^{\Delta \text { loxP/+ }}$ mice $(n=5$, black bars). $\boldsymbol{B}$, Hypogonadism in GnRH-Cre/DTA (striped bar) but not in GnRH-Cre/NSCL-2 $2^{\Delta / x_{P} / \Delta / \text { oxP }}$ (white bars) and GnRH-Cre/NSCL$2^{\Delta l o x P /+}$ (black bars) female mice as indicated by the weight of the uteri. C, Increase of visceral fat mass in GnRH-Crel NSCL-2 $2^{\Delta / 0 x P / \Delta / \text { oxp }}$ female mice (white bars) and GnRH-Cre/DTA female mice ( $n=4$, striped bars) compared with GnRHCre/NSCL-2 $2^{\Delta / x_{P} /+}$ mice (black bar). D, Representative macroscopic images of visceral fat masses and the sizes of uteri and gonads in different models. Uteri were injected with trypan blue to improve visibility. $\boldsymbol{E}$, Reduction of POMC-EGFP neurons in the MPO and PH of POMC-EGFP/GnRH-Cre/NSCL-2 ${ }^{\text {LloxP/D/oxP }}(n=7$, white bars) and POMC-EGFP/GnRH-Cre/DTA ( $n=$ 4 , striped bars) adult female mice compared with POMC-EGFP/GnRH-Cre/NSCL-2 ${ }^{\Delta l o x P /+}$ control mice ( $n=5$, black bars). $F$, Reduction of POMC-EGFP neurons in the MPO, Arc, and PH of adult male POMC-EGFP/GnRH-Cre/NSCL-2 $2^{\Delta \text { loxP/DloxP }}(n=$ 5 , white bars) mutants compared with POMC-EGFP/GnRH-Cre/NSCL-2 $2^{\Delta l o x P /+}$ control mice ( $n=4$, black bars). G, Reduction of GnRH neurons in male GnRH-Cre/NSCL-2 $2^{\Delta / 0 x P / \Delta / o x P}\left(n=5\right.$, white bars) compared with GnRH-Cre/NSCL-2 $2^{\Delta / 0 x P /+}$ $\left(n=4\right.$, black bars) mice. $\boldsymbol{H}$, Normal testis weight of adult male GnRH-Cre/NSCL-2 $2^{\Delta / o x P / \Delta l o x P}$ (white bars) compared with GnRH-Cre/NSCL-2 $2^{\Delta / o x P /+}$ mice (black bars). I, Increase of visceral fat mass in male GnRH-Cre/NSCL-2 $2^{\Delta / o x P / \Delta / \text { oxP }}$ mutants ( $n=5$, white bars) compared with GnRH-Cre/NSCL- $2^{\Delta l o x P /+}$ mice (black bar). ${ }^{*} p<0.05$; ${ }^{* *} p<0.01$; ${ }^{* * *} p<0.001$.
In contrast, Deleter-Cre/NSCL$2^{\Delta l o x P / \Delta l o x P}$ mice displayed a clear increase in body weight and visceral fat depots (Fig. $2 B, E)$. As expected, POMC-Cre/NSCL$2^{\Delta l o x P / \Delta l o x P}$ mice did not show signs of hypogonadotropic hypogonadism (uteri weight, $112 \pm 8 \%$ ) (Fig. 2D) and infertility and generated normal numbers of GnRH neurons (Fig. 2C).

Inactivation of $\mathrm{Nscl}-2$ in GnRH neurons leads to reduction of the number of POMC-expressing cells

The reduction of POMC neurons in Deleter-Cre/NSCL-2 $2^{\Delta \operatorname{loxP} / \Delta \operatorname{loxP}}$ in the presence of normal POMC numbers in POMC-Cre/NSCL- $2^{\Delta \operatorname{lox} P / \Delta \operatorname{lox} P}$ mice suggested that NSCL-2 controls the number of POMC-expressing neurons indirectly probably via a different population of neurons. The transition from supernumerary (before puberty) to missing POMC neurons (after puberty) in NSCL$2^{-1-}$ animals suggested involvement of neurons that play a central role in gonadal and behavioral maturation. GnRH neurons have been identified to exert such a function at puberty onset. Therefore, we generated GnRH-Cre/NSCL-2 $2^{\Delta l o x P / \Delta l o x P} /$ POMC-GFP mice, in which the $\mathrm{Nscl}-2$ gene is specifically inactivated in $\mathrm{GnRH}$ neurons and analyzed the number of POMC neurons in these mice. We detected a severe reduction of POMC neurons in GnRH-Cre/NSCL-2 $2^{\Delta \operatorname{lox} / \Delta \operatorname{lox} P}$ mutants (MPO, $70 \pm 3 \%$; Arc, $81 \pm 7 \%$; $\mathrm{PH}, 40 \pm 5 \%$ ), which recapitulated the reduction of POMC neurons in the MPO and $\mathrm{PH}$ of Deleter-Cre/NSCL-2 $2^{\text {sloxP/AloxP }}$ mice (Fig. 3E). Interestingly, the reduction of POMC neurons in GnRH-Crel NSCL-2 $2^{\Delta \operatorname{lox} P / \Delta \operatorname{lox} P}$ mutants was associated with a significant increase in visceral fat mass $(202 \pm 15 \%)$, demonstrating that the absence of NSCL-2 in GnRH neurons affected POMC numbers and regulation of energy homeostasis (Fig. 3C,D). However, the increase of visceral fat mass in $G n R H-$ Cre/NSCL-2 $2^{\Delta l o x P / \Delta l o x P}$ mutants was clearly below the increase seen in Deleter-Crel NSCL-2 $2^{\Delta l o x P / \Delta l o x P}$ mice, indicating that additional NSCL-2-dependent mechanisms that do not involve POMC and GnRH neurons contribute to the adult onset of obesity in constitutive $N S C L-2^{-1-}$ and Deleter-Crel NSCL-2 $2^{\Delta l o x P / \Delta l o x P}$ mice (Fig. $2 E$ ).

We next wanted to know whether the decline of POMC-expressing neurons in $\mathrm{GnRH}-\mathrm{Cre} / \mathrm{NSCL}-2^{\Delta \text { loxP/DloxP }}$ mutants was associated with reduction of $\mathrm{GnRH}$ neurons. Immunohistochemical staining revealed a $20 \%$ reduction $(80 \pm 6 \%)$ of GnRH neurons, establishing a clear correla- 
tion between reduction of GnRH and POMC neurons. Notably, the reduction was slightly but significantly below the $33 \%$ reduction of GnRH numbers seen in Deleter-Cre/NSCL-2 $2^{\Delta l o x P / \Delta l o x P}$ mice (Figs. $2 C, 3 A)$. Surprisingly, the loss of NSCL-2 in GnRH neurons and the reduction of GnRH neurons in GnRH-Cre/NSCL-2 $2^{\Delta \operatorname{lox} P / \Delta \operatorname{lox} P} \mathrm{mu}-$ tants did not result in a hypogonadotropic hypogonadism (uteri weight, $110 \pm 8 \%$ ) or impaired fertility. In fact, measurement of estradiol levels revealed normal concentrations of estradiol in the serum of GnRH-Cre/NSCL-2 $2^{\Delta l o x P / \Delta l o x P}$ mutants compared with GnRH-Cre/NSCL-2 $2^{\Delta l o x P /+}$ mice, whereas estradiol levels were significantly decreased in ovariectomized mice and Deleter-Cre/NSCL$2^{\Delta l o x P / \Delta l o x P}$ mutants (see Fig. $5 J$ ). Our study mainly focused on female mice, but we also determined the number of POMC and GnRH neurons in male GnRH-Cre/NSCL-2 $2^{\Delta l o x P / \Delta l o x P}$ mutants. We found a similar reduction of the number of POMC-EGFP (Fig. $3 F$ ) and $\mathrm{GnRH}$ (Fig. $3 G$ ) neurons as in female mice and a similar increase in visceral fat mass (Fig. 3I) but normal testis weights (Fig. $3 H$ ), corroborating our findings in female mice (Fig. 3A-E). Although the reduction of GnRH neurons in GnRH-Cre/NSCL-2 $2^{\Delta l o x P / \Delta l o x P} \mathrm{mu}-$ tants did not cause infertility or reduction of estradiol levels, we cannot rule out other indirect effects of the reduced number of $\mathrm{GnRH}$ neurons on visceral obesity and reduction of POMCexpressing neurons. However, we observed a reduction of POMC neurons during postnatal development (Fig. 4A) before accumulation of visceral fat commenced (Fig. $4 C$ ), which excludes that reduction of POMC-expressing neurons is caused by visceral obesity.

Complete ablation of $\mathrm{GnRH}$ neurons recapitulates the loss of POMC neurons in GnRH-Cre/NSCL-2 $2^{\Delta l o x P / \Delta l o x P}$ mutants

To directly address the question whether loss of $\mathrm{GnRH}$ neurons reduces the number of POMC neurons and to exclude the possibility that aberrant synaptic inputs from remaining $\mathrm{Nscl}-2 \mathrm{mu}-$ tant $\mathrm{GnRH}$ neurons contributed to the decline of POMC neurons, we crossed GnRH-Cre/POMC-GFP mice to floxSTOP-DTA mice (Brockschnieder et al., 2004). In these mice, Cre-recombinase-mediated removal of the STOP cassette results in activation of diphtheria toxin A (DTA) and ablation of all cells expressing Cre recombinase. Immunohistochemical staining of $\mathrm{GnRH}$ neurons disclosed a virtually complete absence of $\mathrm{GnRH}$ neurons in GnRH-Cre/POMC-GFP/DTA mice (0.9 $\pm 0.2 \%$ ) (Fig. $3 A$ ). Interestingly, the number of POMC neurons decreased to the same extent as in GnRH-Cre/NSCL-2 $2^{\Delta l o x P / \Delta l o x P}$ mice (MPO, $62 \pm 9 \%$; Arc, $88 \pm 10 \%$; PH, $39 \pm 6 \%$ ), confirming our assumption that inputs from NSCL-2-dependent GnRH neurons control the number of POMC neurons either directly or indirectly (Fig. 3E). Ablation of GnRH neurons also resulted in a similar increase of visceral fat mass $(220 \pm 10 \%)$ as in GnRHCre/NSCL-2 $2^{\Delta l o x P / \Delta l o x P}$ mice (Fig. $3 C, D$ ). Together, our data suggest that the increase in visceral fat mass follows the loss of POMC neurons and is not simply caused by altered concentrations of sex steroids in GnRH-Cre/NSCL-2 $2^{\Delta l o x P / \Delta l o x P}$ mutants, although we cannot exclude that secondary mechanisms contribute to this phenomenon.

The absence of GnRH neurons also resulted in hypogonadotropic hypogonadism and infertility. The weight of uteri and size of ovaries in GnRH-Cre/POMC-GFP/flox-STOP-DTA mice was strongly reduced (uteri weight, $20 \pm 17 \%$ ), although the reduction was less pronounced compared with Deleter-Cre/NSCL$2^{\Delta \operatorname{lox} P / \Delta \operatorname{lox} P}$ (uteri weight, $4 \pm 0.6 \%$ ) (Figs. $2 D, 3 B, D$ ), which indicates that additional regulatory circuits distinct from the GnRH system but dependent on NSCL-2 affect maturation of secondary sexual characteristics. In contrast, the release of

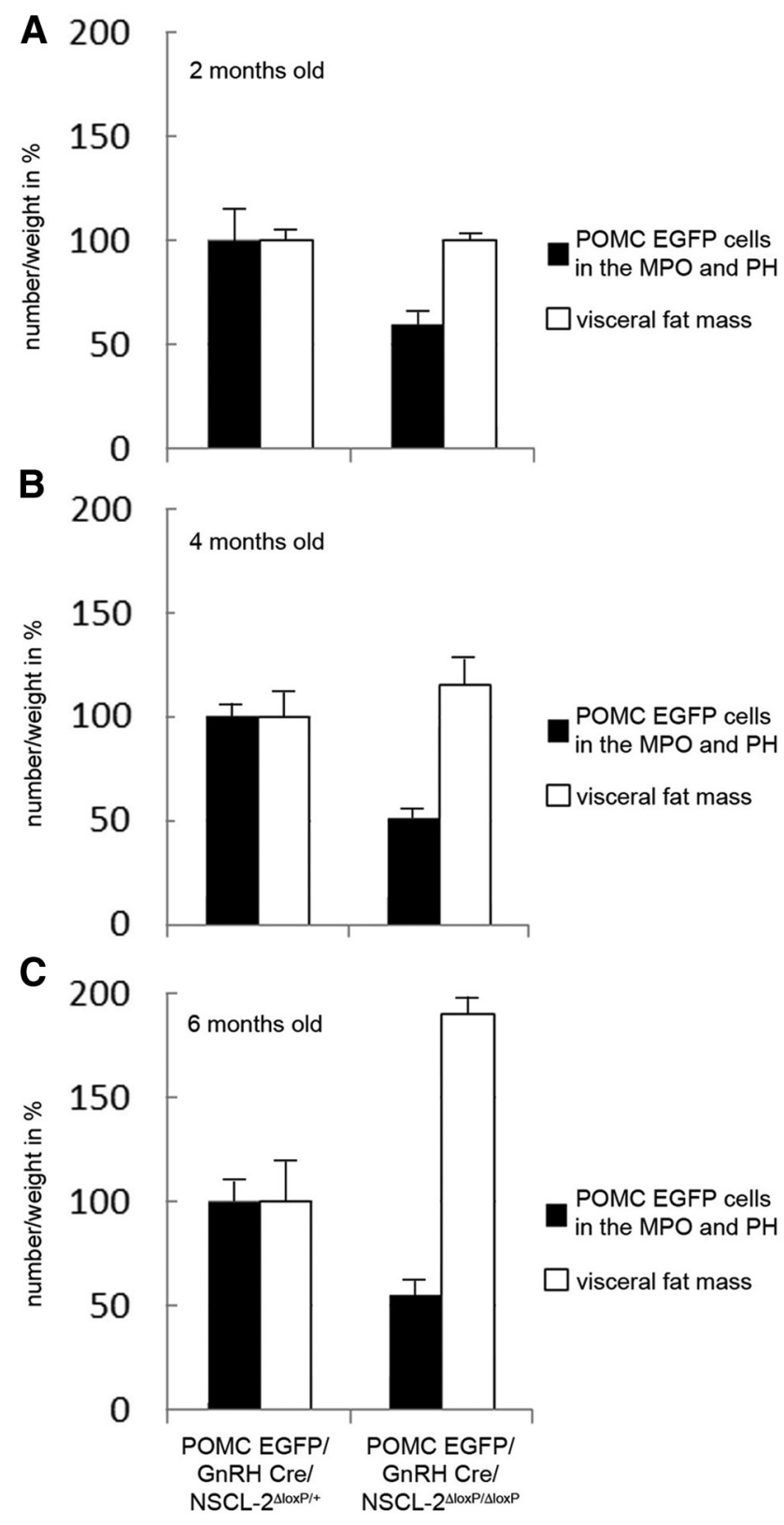

Figure 4. Reduction of POMC-GFP neurons precedes development of visceral obesity in GnRH-Cre/NSCL-2 $2^{\Delta /{ }^{\prime o x P} / \Delta / \text { oxP }}$ female mice. $A-C$, Reduction of POMC-EGFP neurons in the MPO and $\mathrm{PH}$ (black bars) of female POMC-EGFP/GnRH-Cre/NSCL-2 $2^{\Delta / o x P / \Delta / o x P}$ mutants versus $P O M C-E G F P / G n R H-C r e / N S C L-2^{\Delta l o x P /+}$ littermates at different ages compared with the increase of visceral fat mass (white bars).

follicle-stimulating hormone and $\mathrm{LH}$ was completely dependent on the presence of GnRH neurons (data not shown).

Increased visceral fat mass accumulation after ovariectomy or reproductive senescence is associated with reduction of GnRH and POMC neurons

So far, we demonstrated that genetic manipulation of the number of GnRH neurons resulted in a reduction of POMC-expressing neurons and increased visceral mass accumulation, which provides a mechanistic explanation for the close association between hypogonadism and obesity. We reasoned that the gain in visceral body fat both in reproductively senescent women (Ley et al., 1992) as well as in mice after ovariectomy (Yepuru et al., 2010) might be based on a similar mechanism. Therefore, we investi- 
A
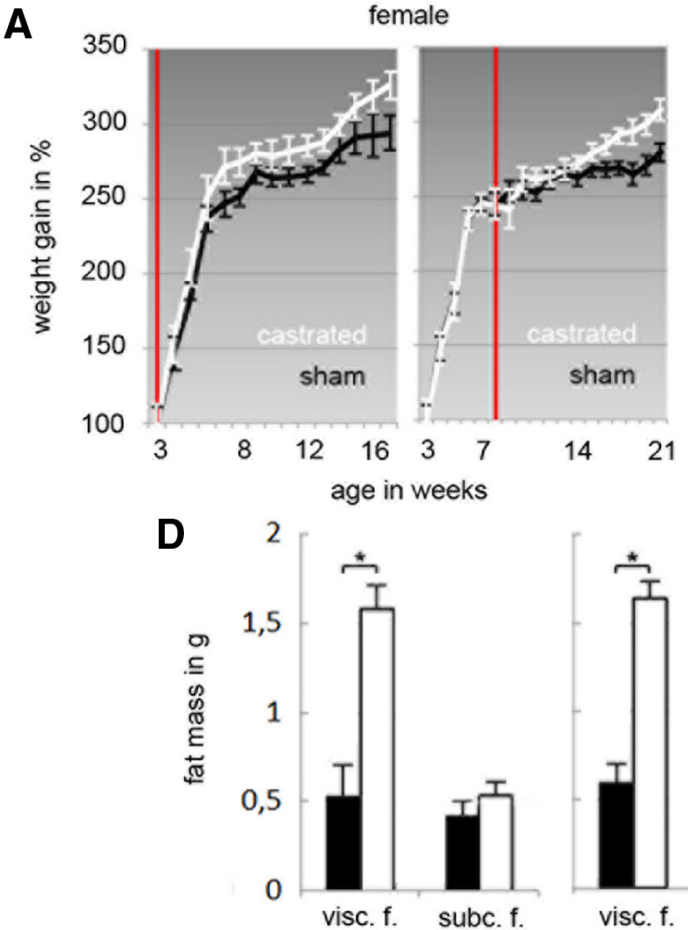

$\mathbf{F}$

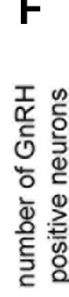

20 months old POMC EGFP female mice (no obesity)

20 months old POMC EGFP female
B

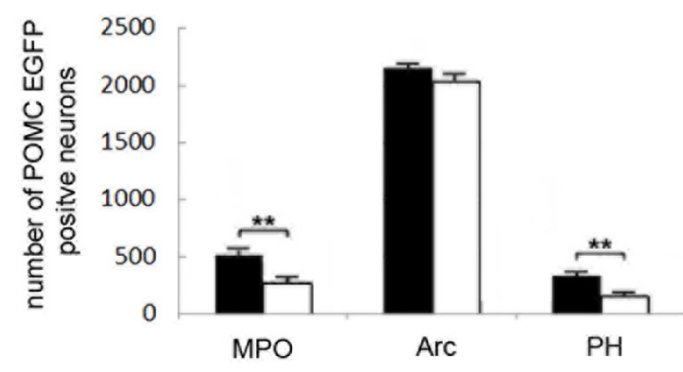

E
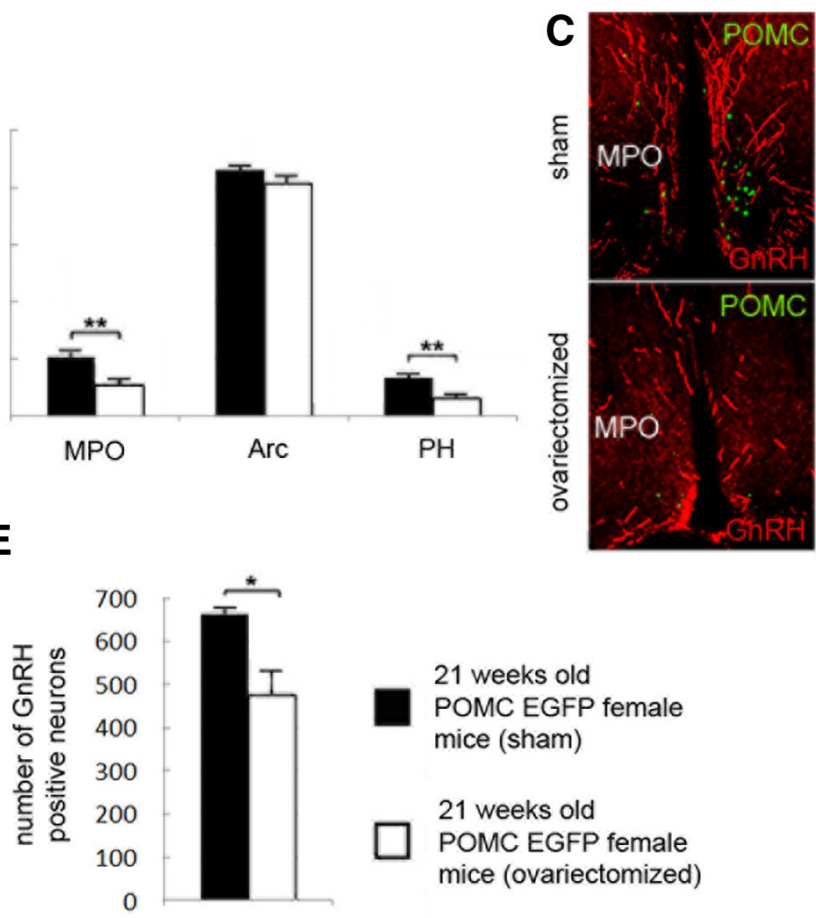

visc. f. subc. $f$

G
H

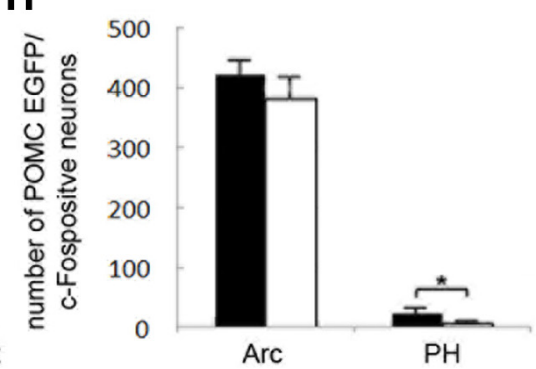

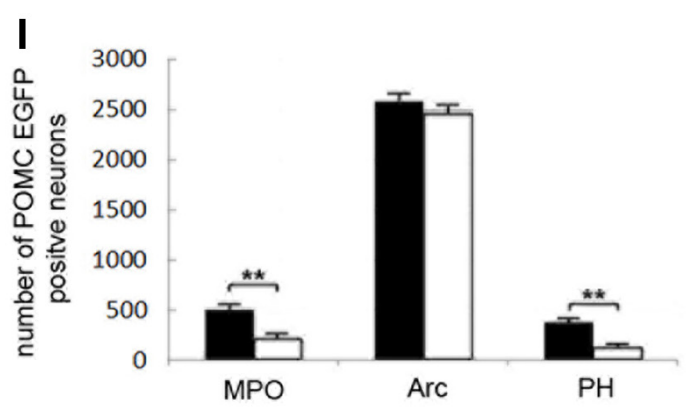
mice (visceral obesity)
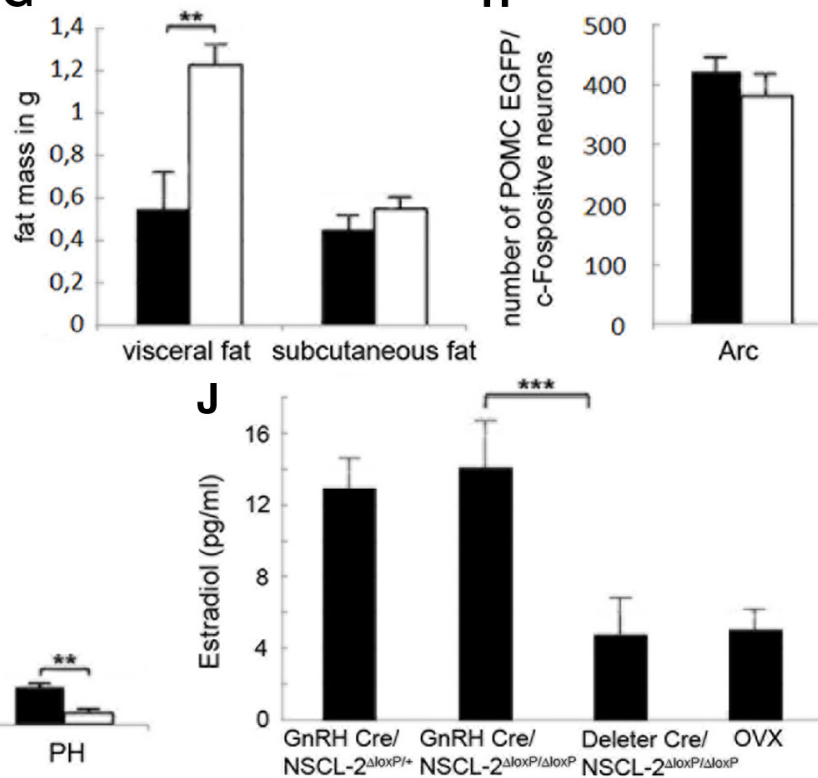

Figure 5. Reduction of POMC neurons in POMC-GFP female mice after ovariectomy. $A$, Increased gain of weight after ovariectomy (OBX) $(n=5$, white line) compared with sham-operated female mice ( $n=5$, black line). $\boldsymbol{B}$, Significant reduction of POMC-GFP cells in the MPO and PH after OBX (white bars) compared with sham-operated control mice (black bars). $\boldsymbol{C}$, GnRH immunostaining of coronal sections of POMC-GFP female mice demonstrating reduction of GnRH fibers and POMC-positive cells in OBX compared with control mice. $\boldsymbol{D}$, Increased visceral but not subcutaneous fat mass in OBX mice. E, Decreased number of GnRH-positive neurons in OBX (white bar) compared with control mice (black bar). $\boldsymbol{F}$, Reproductively senescent POMC-GFP mice with a significant reduction of GnRH neurons (white bar) show visceral obesity compared with age-matched control mice with regular number of GnRH neurons (black bar) ( $n=5$ ). $\mathbf{G}$, Reproductively senescent mice with reduced number of GnRH neurons (white bars) show an increase of visceral but not subcutaneous fat mass compared with age-matched control mice with regular number of GnRH neurons (black bar). $\boldsymbol{H}$, Remaining POMC neurons in reproductively senescent obese mice (white bars) express c-Fos after administration of leptin to the same extent as age-matched non-obese control mice (black bars). Reduced numbers of c-Fos-positive POMC neurons in the PH is attributable to the reduction of POMC-GFP cells in the PH of reproductively senescent obese mice. $I$, Reproductively senescent mice with reduced numbers of GnRH neurons and visceral obesity (white bars) show a significant reduction of POMC neurons in the MPO and PH compared with the non-obese control group (black bars). J, GnRH-Cre/NSCL-2 $2^{\Delta / 0 x P / \Delta / o x P}$ mutants $(n=4)$ show no changes in estradiol levels compared with GnRH-Cre/NSCL-2 $2^{\Delta / o x P /+}$ control mice $(n=4)$. Ovariectomized and hypogonadotropic Deleter-Cre/NSCL-2 ${ }^{\Delta / o x p / \Delta / o x P}$ female mice ( $n=4$ in each group) show decreased serum estradiol levels. ${ }^{*} p<0.05 ;{ }^{* *} p<0.01 ;{ }^{* * * *} p<0.001$.

gated whether the absence of signals from the gonads after ovariectomy and reproductive senescence in female mice might also reduce the number of GnRH cells and thereby affect POMC neurons and visceral obesity. Ovaries were surgically removed in two groups of female POMC-GFP mice $(n=5)$ at 3 weeks (prepu- bertal) and 8 weeks (postpubertal) of age and compared with corresponding sham-operated mice. Regardless of the time point of ovariectomy, operated mice showed an increase of the overall body weight compared with control groups (Fig. 5A) and, more significantly, of the visceral but not of the subcutaneous fat, 
which strongly resembled changes seen in GnRH-Cre/NSCL$2^{\Delta l o x P / \Delta l o x P}$ mice (Fig. 3D). Interestingly, we observed a significant reduction of $\mathrm{GnRH}$ neurons $(68 \pm 11 \%)$ and POMC neurons in the MPO and PH (MPO, $52 \pm 8 \%$; Arc, $94 \pm 6 \%$; PH, $45 \pm 4 \%$ ) in ovariectomized compared with sham-operated mice at 21 weeks of age (Fig. $5 B, C, E$ ), phenocopying the reduction of $\mathrm{GnRH}$ and POMC neurons in GnRH-Cre/NSCL-2 $2^{\Delta l o x P / \Delta l o x P}$ mutants. Similar results were obtained in groups of reproductively senescent female POMC-GFP mice with and without visceral obesity at 20 months of age $(n=5)$ (Fig. $5 G)$. We found a reduction of GnRH neurons (74 $\pm 4 \%$ ) and POMC-GFP neurons within the MPO and PH (MPO, $41 \pm 5 \%$; Arc, $93 \pm 6 \%$; PH, $27 \pm 2 \%$ ) of reproductively senescent mice with visceral obesity but not in non-obese mice (Fig. $5 F, I$ ). To investigate whether remaining POMC neurons are functionally active, we analyzed the expression of c-Fos after injection of leptin. No significant differences in the number of c-Fos-positive POMC neurons were observed in the Arc of obese compared with non-obese reproductively senescent mice, although we detected a slight reduction in the PH (Fig. $5 H$ ). Together, the reduction of GnRH neurons in ovariectomized and reproductively senescent mice was associated with the same decline of POMC neurons and the same increase of visceral obesity as in our genetic models based on the deletion of $\mathrm{Nscl}-2$ in $\mathrm{GnRH}$ neurons or ablation of GnRH neurons. Of course, it is not unlikely that, in contrast to our genetic models, the reduction of estrogen secretion in ovariectomized (Fig. 5J) and reproductively senescent mice had additional effects on visceral fat mass accumulation.

Aberrant accumulation of $\mathrm{Nscl}$-2-deficient, GnRH-neuronderived cells in septal regions is associated with diminished colonization of the Arc by GnRH-expressing neurons

So far, we demonstrated that inactivation of $\mathrm{Nscl}-2$ in $\mathrm{GnRH}$ neurons leads to a reduction of GnRH neurons and prevents survival of regular numbers of POMC neurons, resulting in increase of visceral fat mass. However, it remained unclear in which anatomical location the depletion of $\mathrm{GnRH}$ neurons occurred and why GnRH neurons were lost after inactivation of NSCL-2. GnRH neurons are defined by expression of GnRH, which makes it difficult to follow the fate of these cells, once GnRH expression is lost. To circumvent this problem and to enable permanent tracing of GnRH-derived cells, we generated GnRH-Cre/NSCL$2^{\Delta l o x P /+} /$ Rosa26LacZ mice and GnRH-Cre/NSCL-2 $2^{\Delta l o x P / \Delta l o x P} /$ Rosa26LacZ mice. In these mice, all cells that once expressed $\mathrm{GnRH}$ are permanently labeled by expression of LacZ regardless of the current state of GnRH activity. Quantitative assessment revealed that $95 \pm 1 \%$ of all GnRH-expressing cells were also LacZ positive (Fig. $6 A, B$ ), indicating the validity of this tracing approach. We assume that the failure to detect GnRH-Creinduced LacZ expression in all GnRH neurons is attributable to technical limitations of double labeling.

In GnRH-Cre/NSCL-2 $2^{\Delta l o x P /+} /$ Rosa26LacZ mice, the majority of GnRH-derived cells switched off GnRH expression and became located to septal areas. Only a relatively small population completed the journey from the olfactory placode to the MPO and Arc and retained GnRH expression (Fig. 6C). Apparently, maintenance of $\mathrm{GnRH}$ expression and terminal differentiation of GnRH neurons depend critically on acquisition of correct anatomical locations in the MPO and the Arc, which is achieved only by a minority of GnRH-derived cells in the absence of NSCL-2. Interestingly, the number of GnRH-positive and LacZ-positive cells declined in the Arc of GnRH-Cre/NSCL-2 $2^{\Delta l o x P / \Delta l o x P} /$ Rosa26LacZ mutants (Arc-GnRH, $31 \pm 14 \%$; LacZ, $69 \pm 2 \%$ ),
A

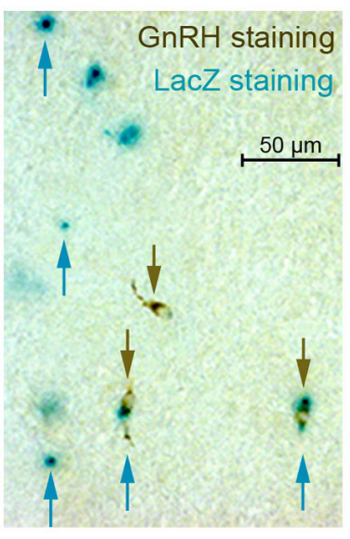

B

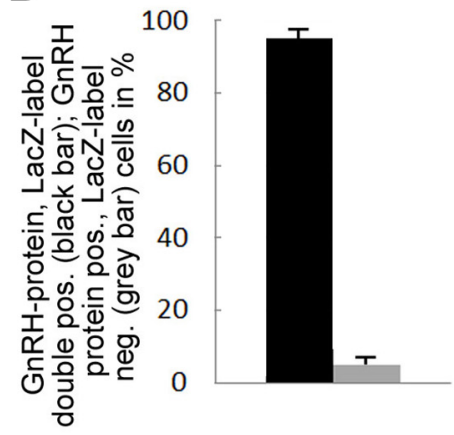

C
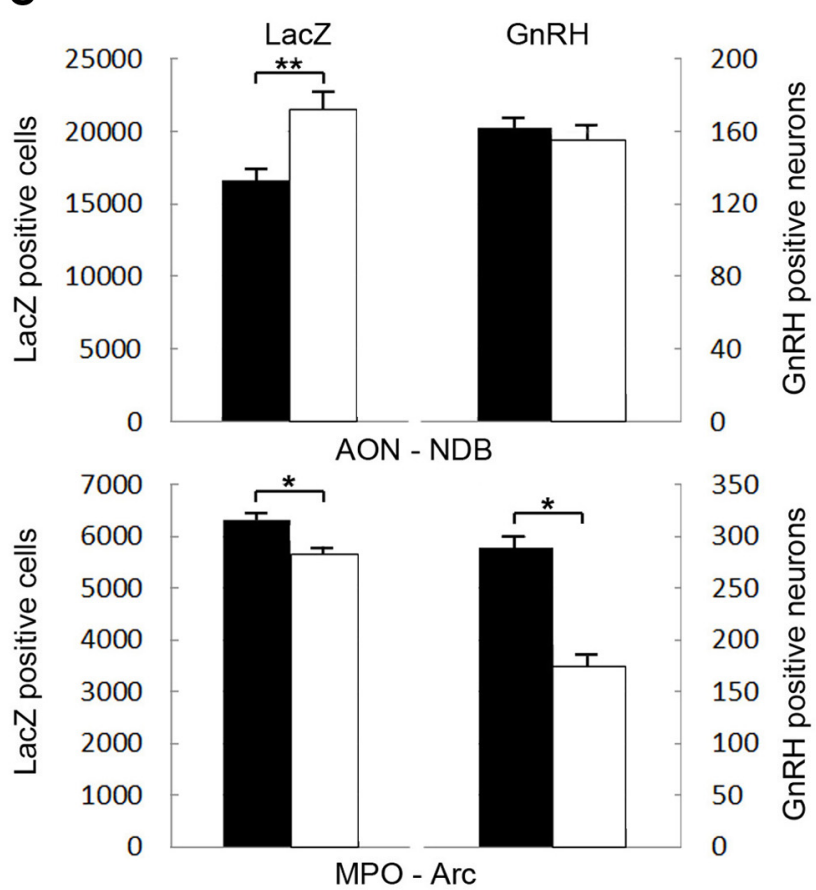

Figure 6. Accumulation of GnRH neurons in the septum after inactivation of $\mathrm{Nscl}-2$ in GnRH neurons. Lineage tracing of neurons that have expressed $\mathrm{GnRH}$ during development using $\mathrm{GnRH}$-Cre and Rosa26 LacZ reporter mice with and without inactivation of $\mathrm{NsCl}-2$ in GnRH neurons. $A, B$, Double staining of coronal sections through the hypothalamus of $\mathrm{GnRH}-\mathrm{Cre} / \mathrm{NSCL}$ $2^{\Delta / o x P /+} / R 0 S A 26 L a C Z$ mice for GnRH (brown) and LacZ (blue) reveals that only a small fraction of neurons ( $\sim 5 \%$ ) that have expressed $\mathrm{GnRH}$ during development maintain $\mathrm{GnRH}$ expression during adulthood. Number of $\mathrm{GnRH}-\mathrm{Cre} / \mathrm{NSCL}-2^{\Delta / x_{P} /+} / \mathrm{ROSA} 26 \mathrm{LaCZ}$ and $\mathrm{GnRH}$ protein double-positive cells (black bar) and GnRH-Cre/NSCL-2 $2^{\Delta / o x P /+} / R O S A 26 L a C Z-n e g a t i v e, ~ G n R H-$ protein-positive cells (gray bar). C, Quantitative evaluation of LacZ- and GnRH-positive cells in different brain regions of GnRH-Cre/NSCL-2 $2^{\Delta / 0 x P /+} / R O S A 26 L a C Z$ ( $n=5$, black bars) and GnRH-Cre/NSCL-2 $2^{\Delta / 0 x P / \Delta / o x P} /$ ROSA26LaCZ ( $n=4$, white bars) adult female mice. Note the increased number of LacZ-positive cells between the anterior olfactory nucleus (AON) and nucleus of the diagonal band (NDB) as well as decreased number of GnRH- and LacZ-positive cells in the MPO of GnRH-Cre/NSCL-2 $2^{\Delta / o x P / \Delta / o x P} /$ ROSA26LaCZ mice. ${ }^{*} p<0.05$; ${ }^{* *} p<0.01$.

whereas the number of LacZ-positive but not GnRH-positive cells increased in septal areas and the diagonal band of Broca (DBB) (septal-GnRH, $78 \pm 15 \%$ and LacZ, $203 \pm 13 \%$; DBBGnRH, $92 \pm 10 \%$ and LacZ, $262 \pm 8 \%$ ) (Fig. 7). These changes corresponded to an accumulated absolute increase of LacZ and decrease of GnRH neurons (Fig. 6C). The absence of NSCL-2 in GnRH neurons obviously leads to precocious termination of mi- 

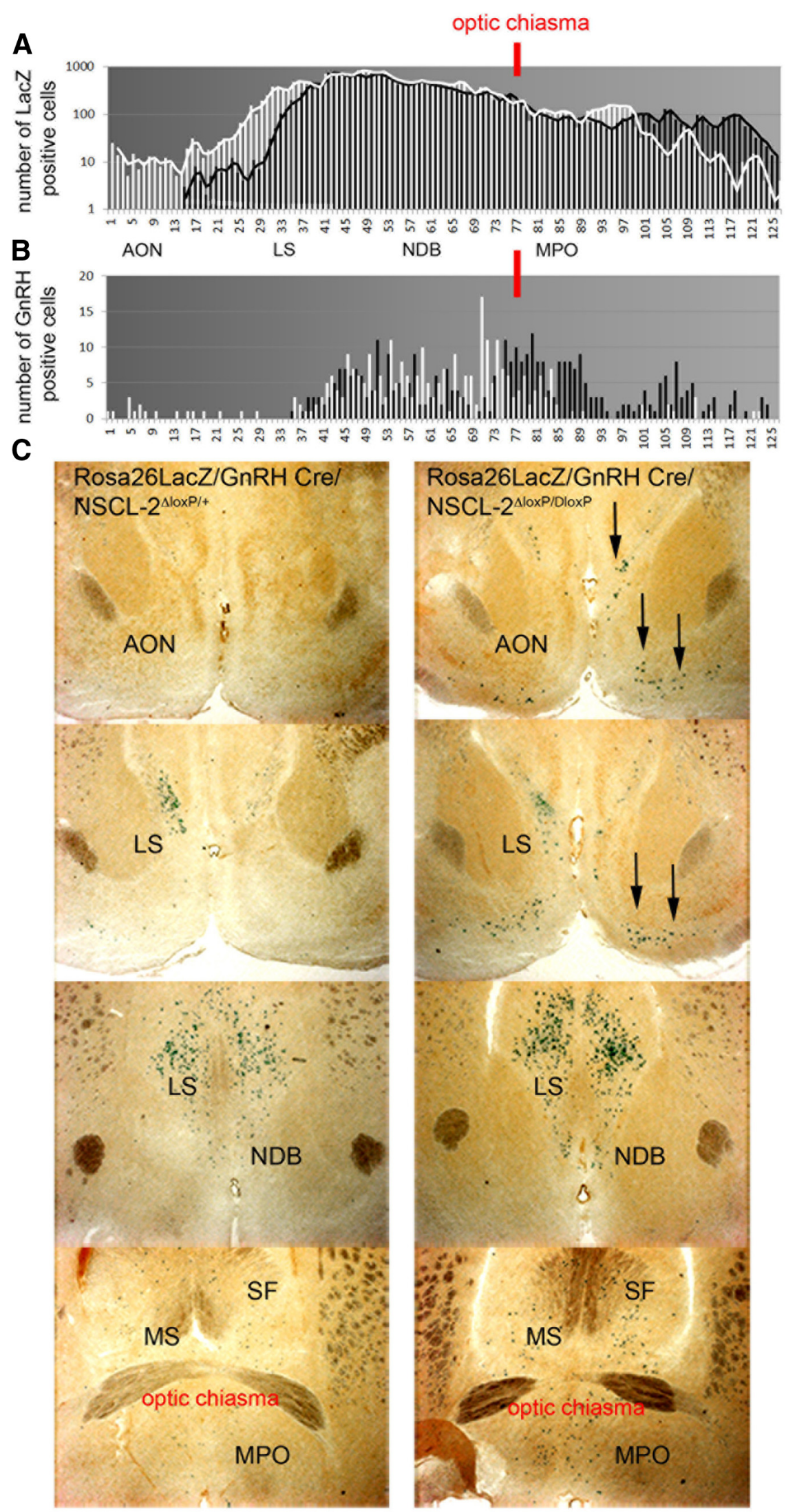

Figure 7. Lineage tracing of $\mathrm{GnRH}$ neurons after inactivation of Nscl-2 in GnRH neurons. $\boldsymbol{A}, \boldsymbol{B}$, Number of LacZ-positive $(\boldsymbol{A})$ and GnRH-positive $(\boldsymbol{B})$ cells in GnRH-Cre/NSCL-2 $2^{\Delta / o x P / \Delta} / \mathrm{LaCZ}$ (black bars) and GnRH-Cre/NSCL-2 $2^{\Delta / o x P / \Delta / o x P} / L a C Z$ (white bars) adult female mice. C, Representative coronal sections after LacZ staining in GnRH-Cre/NSCL-2 $2^{\Delta / o x P /+} / \mathrm{LacZ}$ (right) and GnRH-Cre/NSCL$2^{\Delta / o x P / \Delta / \text { oxP }} / L a c Z$ female mice. Note the ectopic location of LacZ-positive cells in the anterior olfactory nucleus of GnRH-Cre/NSCL$2^{\Delta / \text { oxP/DIoxP }} /$ LacZ mice compared with GnRH-Cre/NSCL-2 $2^{\Delta / o x P /+} / L a c Z$ control mice. AON, Anterior olfactory nucleus; LS, lateral gration and subsequent loss of GnRH expression but does not affect survival of Nscl-2-deficient GnRH-derived cells, which accumulate in more anterior regions of the brain, such as septal regions and the DBB. The specific reduction of $\mathrm{GnRH}$ neurons in the MPO and Arc of GnRH-Cre/NSCL-2 $2^{\Delta l o x P / \Delta l o x P}$ mice raises the possibility that lack of synaptic inputs from this particular population of $\mathrm{GnRH}$ neurons on POMC neurons is responsible for decreased survival of POMC neurons.

\section{Discussion}

A plethora of signals, including metabolic hormones and neuropeptides, has been identified that confers the nutritional status to hypothalamic centers controlling reproduction. It has long been noted that the state of energy reserves is instrumental for the onset of puberty in mammals (Parent et al., 2003). The necessity of a coupling between nutritional status and onset of puberty is particularly evident for females that need considerable energy reserves to successfully maintain pregnancy and nurse offspring. In contrast, surprisingly little attention has been paid to the possible impact of neuronal circuits controlling reproduction on the regulation of energy reserves, although there is clear evidence of a close association between hypogonadism and obesity, such as in patients suffering from adiposogenital dystrophy (Babinski-Froehlich syndrome), Prader-Willi syndrome, and Turner syndrome (Lempp, 1957; Krüger et al., 2004; Ostberg et al., 2005). Moreover, it is well established that reproductive senescence is associated with gains in visceral body fat in both reproductively senescent women (Ley et al., 1992) and mice after ovariectomy (Yepuru et al., 2010), further emphasizing the inverse correlation between reproductive abilities and obesity.

\section{The deletion of $\mathrm{Nscl}-2$ in distinct} neuronal subpopulations reveals a link between obesity and infertility

Here, we have shown that loss of $\mathrm{Nscl}-2$ in $\mathrm{GnRH}$ neurons causes a decline of the number of GnRH neurons and a decrease of POMC-expressing neurons. Our work provides a molecular concept for a better understanding of the effects of sexual maturation on body weight regulation and provides evidence for a bidirectional flow of information between systems con-

septal nucleus; NDB, nucleus of the diagonal band; SF, septofimbrial nucleus; MS, medial septal nucleus. 
trolling sexual reproduction and energy balance. Interestingly, obesity has also been described in some patients suffering from Kallmann syndrome, characterized by loss of GnRH neurons (Dod é et al., 2006; Abreu et al., 2008). However, obesity is not evident in all Kallmann patients, which might be attributable to the complex nature of the disease and additional phenotypic effects of genes causing this condition (Sarfati et al., 2010).

Using a panel of cell-type-specific Crerecombinase driver mice, we analyzed the role of a loss of $\mathrm{Nscl}$-2 expression for adult onset of obesity and hypogonadotropic hypogonadism in different neuronal cell populations. We did not detect any increase of visceral fat mass or infertility after inactivation of $\mathrm{Nscl}-2$ in POMC neurons, which are well known for their role in regulating energy balance and neuroendocrine functions. These results were surprising because we found an absence of $\alpha$-MSH and ACTH production in the majority of POMC neurons lacking $\mathrm{Nscl}-2$, which corroborates the critical role of NSCL-2 in directing expression of $\mathrm{PC} 1 / 3$. Obviously, expression of $\alpha-\mathrm{MSH}$ and ACTH in the majority of POMC neurons is dispensable for normal body weight regulation, at least under our experimental conditions. In contrast, the POMC neurons, in which expression of $\mathrm{PC1} / 3$ (or another pro-hormone convertase) does not depend on NSCL-2, seem sufficient to prevent obesity, defective adrenal development, and altered pigmentation seen in POMC knock-out mice (Yaswen et al., 1999). In addition, it is possible that a large POMC precursor protein or other molecules that might be produced in $\mathrm{Nscl}$-2-deficient POMC neurons have yet unknown functions in the melanocortin pathway. Such mechanisms might be particularly important for POMC neurons in the MPO and PH, which do not normally process POMC. Despite these open questions, we can rule out that the metabolic changes in $\mathrm{Nscl}-2$ mutants are attributable to decreased $\alpha$-MSH and ACTH expression in POMC neurons.

We found that reduction of the number of GnRH neurons caused by inactivation of $\mathrm{Nscl}-2$ in these cells and a complete ablation of all GnRH neurons was associated with a decline of POMC-expressing numbers and an increase in visceral fat mass. Interestingly, the reduction coincided with the onset of puberty, suggesting that the well-known change of activity of GnRH neurons at puberty prevents cell death of a subpopulation of POMC neurons or prevents cessation of POMC expression. The fact that the reduction of POMC-expressing neurons occurred after puberty fits nicely with the adult onset of obesity in $\mathrm{Nscl}-2$ mutant mice and is consistent with an important role of a subset of POMC neurons in the increase of visceral fat mass. Our results show that the absence of a group of POMC-expressing neurons but not the missing release of $\alpha$-MSH and ACTH from $\mathrm{Nscl}-2$ mutant POMC neurons is linked to the increase of visceral fat mass. Interestingly, this subgroup of POMC neurons seems not to respond to leptin stimulation as indicated by the absence of c-Fos expression after administration of leptin. The results from our genetic models were also corroborated by analysis of ovari-

\section{Loss of NSCL-2 dependent GnRH neurons}

Reproduction $\longrightarrow$ Metabolism

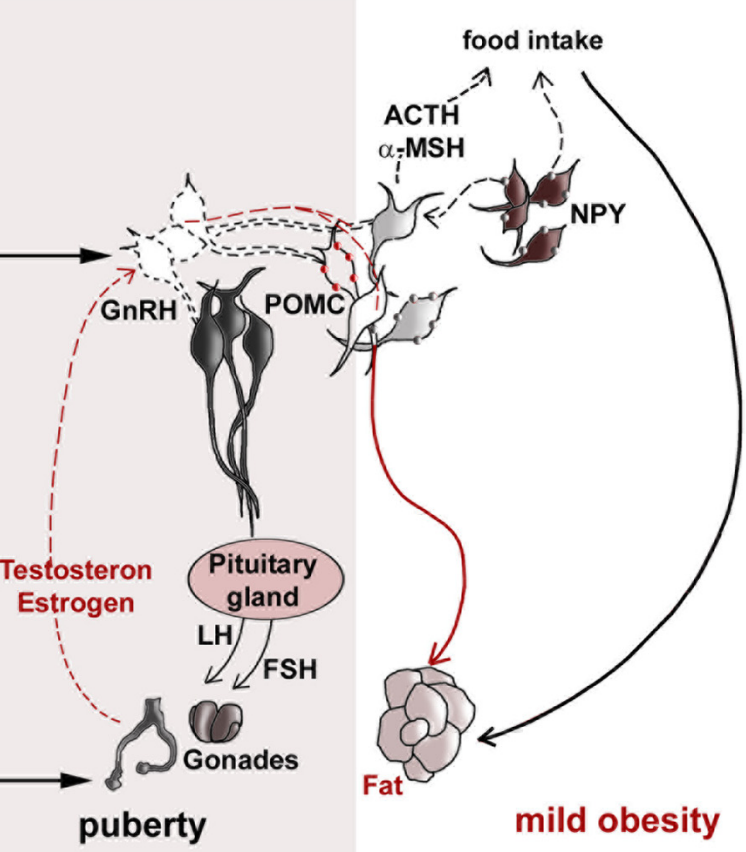

puberty

mild obesity increase of visceral fat mass. Effects of the lack of estrogen on body weight have been mostly explained by direct influence of steroid hormones on the metabolism ignoring a potential influence on regulatory neuronal cell populations (Mattiasson et al., 2002). However, we found that ovariectomy and reproductive senescence lead to a reduction of GnRH and POMC neurons together with an increase of visceral fat mass strikingly phenocopying the loss of $\mathrm{Nscl}-2$ in $\mathrm{GnRH}$ neurons. We postulate that the newly discovered functional link between GnRH and POMC neurons plays an import part in the development of visceral obesity after reproductive senescence and ovariectomy, although the reduction of female sex hormones will have a direct effect on the metabolism of white adipose tissue. Despite the accumulated evidence, we cannot completely rule out that the loss of Nscl-2 in $\mathrm{GnRH}$ neurons initiates other processes that cause visceral obesity independent of the reduction of POMC neurons. However, we can exclude that such hypothetic mechanisms rely on major changes in estrogen production because female GnRH-Crel NSCL-2 $2^{\Delta \operatorname{lox} P / \Delta \operatorname{lox} P}$ mutant mice showed normal serum estradiol concentration, were fertile, and bred normally.

At present, we do not know whether the missing subpopulation of POMC neurons exerts a specific role in the regulation of fat mass or whether reduction of the absolute number of POMC neurons is important, nor do we know the precise mechanism behind this phenomenon. Conversely, we observed a reduction of the number of POMC neurons before increase of visceral obesity, which argues against a secondary reduction of POMC neurons caused by metabolic processes. Our results are in line with the central role of POMC neurons in the regulation of body weight and energy homeostasis. Figure 8 depicts our current view of NSCL-2/POMC neuron-dependent 
processes in cellular systems controlling reproduction and energy balance.

\section{NSCL-2 has multiple functions in the regulation of body weight}

The increase of visceral fat mass in GnRH-Cre/NSCL-2 $2^{\Delta \operatorname{lox} P / \Delta l o x P}$ mice only partially recapitulates the adult onset of obesity in constitutive Nscl-2 mutant mice, suggesting that several distinct NSCL-2-dependent mechanisms are involved in the regulation of body weight. In fact, it has been reported recently that NSCL-2 directly regulates the MC4R promoter, which might explain reduced hypothalamic expression of MC4R mRNA in constitutive Nscl-2 knock-out mice (Wankhade and Good, 2011). Interestingly, specific inactivation of the leptin receptor in POMC neurons (Balthasar et al., 2004) yielded a similar increase of fat mass as conditional inactivation of NSCL-2 in GnRH neurons (which resulted in a reduction of the number of POMC neurons). Based on their results, Balthasar et al. concluded that leptin-mediated regulation of MC4R via $\alpha-\mathrm{MSH}$ plays only a small role in controlling body weight, leading to the hypothesis that MC4Rindependent actions of leptin could be mediated by additional factors released by POMC neurons, such as the neuropeptide CART (cocaine and amphetamine-regulated transcript) (Elias et al., 1998) or the neurotransmitter glutamate (Collin et al., 2003). Our data are in agreement with this hypothesis because the lack of $\alpha$-MSH generation in the majority of POMC neurons (in POMC-Cre/NSCL- $2^{\Delta l o x P / \Delta l o x P}$ mice) failed to increase fat mass, whereas loss of a subset of POMC neurons (in GnRH-Cre/NSCL$2^{\Delta l o x P / \Delta l o x P}$ mice) enlarged the visceral fat. Nevertheless, it is possible that other not yet identified mechanisms contribute to the obesity phenotype because NSCL-2 is widely expressed in the developing CNS and PNS.

\section{Loss of Nscl-2 leads to precocious termination of migration of GnRH neurons and initiates a switch in cell fate}

We previously speculated that the severe reduction of $\mathrm{GnRH}$ neurons in Nscl-2 mutant mice is most likely caused by a cellautonomous migration defect (Krüger et al., 2004), but we were unable to definitively prove this hypothesis because we could not trace $\mathrm{Nscl}$-2-defective GnRH neurons that had lost GnRH expression. The inactivation of $\mathrm{Nscl}-2$ in GnRH neurons combined with activation of a stable cellular marker allowed us to resolve this shortcoming and trace Nscl-2-deficient GnRH neurons. The accumulation of $\mathrm{Nscl}$-2-deficient GnRH-neuron-derived cells in septal areas and the DBB, which are situated along the migratory path of GnRH neurons to the MPO and Arc, suggests precocious termination of migration and reinforces our original hypothesis that NSCL-2 is involved in the transcriptional control of migration of GnRH neurons. It was also interesting to note that $\mathrm{GnRH}$ neurons located at an ectopic position "forgot" their initial identity and adopted a different fate as indicated by the loss of GnRH expression. It is tempting to speculate that $\mathrm{GnRH}$ neurons receive specific signals at their location within the MPO and Arc to maintain identity and function.

Together, the analysis of the function of NSCL-2 in multiple distinct neuronal cell populations in the hypothalamus unveiled a hitherto unknown regulatory role of NSCL-2-dependent GnRH neurons in the control of POMC cells and visceral fat mass. Our study might provide a starting point for a more thorough analysis of the impact of the reproductive system for the control of energy expenditure and regulation of fat mass.

\section{References}

Abreu AP, Trarbach EB, de Castro M, Frade Costa EM, Versiani B, Matias Baptista MT, Garmes HM, Mendonca BB, Latronico AC (2008) Lossof-function mutations in the genes encoding prokineticin-2 or prokineticin receptor-2 cause autosomal recessive Kallmann syndrome. J Clin Endocrinol Metab 93:4113-4118. CrossRef Medline

Arble DM, Vitaterna MH, Turek FW (2011) Rhythmic leptin is required for weight gain from circadian desynchronized feeding in the mouse. PLoS One 6:e25079. CrossRef Medline

Balthasar N, Coppari R, McMinn J, Liu SM, Lee CE, Tang V, Kenny CD, McGovern RA, Chua SC Jr, Elmquist JK, Lowell BB (2004) Leptin receptor signaling in POMC neurons is required for normal body weight homeostasis. Neuron 42:983-991. CrossRef Medline

Brockschnieder D, Lappe-Siefke C, Goebbels S, Boesl MR, Nave KA, Riethmacher D (2004) Cell depletion due to diphtheria toxin fragment A after Cre-mediated recombination. Mol Cell Biol 24:7636-7642. CrossRef Medline

Campbell RE, ffrench-Mullen JM, Cowley MA, Smith MS, Grove KL (2001) Hypothalamic circuitry of neuropeptide $\mathrm{Y}$ regulation of neuroendocrine function and food intake via the Y5 receptor subtype. Neuroendocrinology 74:106-119. CrossRef Medline

Collin M, Bäckberg M, Ovesj ö ML, Fisone G, Edwards RH, Fujiyama F, Meister B (2003) Plasma membrane and vesicular glutamate transporter mRNAs/proteins in hypothalamic neurons that regulate body weight. Eur J Neurosci 18:1265-1278. CrossRef Medline

Cowley MA, Smart JL, Rubinstein M, Cerdán MG, Diano S, Horvath TL, Cone RD, Low MJ (2001) Leptin activates anorexigenic POMC neurons through a neural network in the arcuate nucleus. Nature 411:480-484. CrossRef Medline

Crown A, Clifton DK, Steiner RA (2007) Neuropeptide signaling in the integration of metabolism and reproduction. Neuroendocrinology 86:175182. CrossRef Medline

Dod é C, Teixeira L, Levilliers J, Fouveaut C, Bouchard P, Kottler ML, Lespinasse J, Lienhardt-Roussie A, Mathieu M, Moerman A, Morgan G, Murat A, Toublanc JE, Wolczynski S, Delpech M, Petit C, Young J, Hardelin JP (2006) Kallmann syndrome: mutations in the genes encoding prokineticin-2 and prokineticin receptor-2. PLoS Genet 2:e175. CrossRef Medline

Elias CF, Lee C, Kelly J, Aschkenasi C, Ahima RS, Couceyro PR, Kuhar MJ, Saper CB, Elmquist JK (1998) Leptin activates hypothalamic CART neurons projecting to the spinal cord. Neuron 21:1375-1385. CrossRef Medline

Elmquist JK (2001) Hypothalamic pathways underlying the endocrine, autonomic, and behavioral effects of leptin. Int J Obes Relat Metab Disord 25 [Suppl 5]:S78-S82.

Fox DL, Good DJ (2008) Nescient helix-loop-helix 2 interacts with signal transducer and activator of transcription 3 to regulate transcription of prohormone convertase 1/3. Mol Endocrinol 22:1438-1448. CrossRef Medline

Good DJ, Porter FD, Mahon KA, Parlow AF, Westphal H, Kirsch IR (1997) Hypogonadism and obesity in mice with a targeted deletion of the Nhlh2 gene. Nat Genet 15:397-401. CrossRef Medline

Haisenleder DJ, Schoenfelder AH, Marcinko ES, Geddis LM, Marshall JC (2011) Estimation of estradiol in mouse serum samples: evaluation of commercial estradiol immunoassays. Endocrinology 152:4443-4447. CrossRef Medline

Jackson RS, Creemers JW, Ohagi S, Raffin-Sanson ML, Sanders L, Montague CT, Hutton JC, O’Rahilly S (1997) Obesity and impaired prohormone processing associated with mutations in the human prohormone convertase 1 gene. Nat Genet 16:303-306. CrossRef Medline

Jing E, Nillni EA, Sanchez VC, Stuart RC, Good DJ (2004) Deletion of the Nhlh2 transcription factor decreases the levels of the anorexigenic peptides alpha melanocyte-stimulating hormone and thyrotropin-releasing hormone and implicates prohormone convertases I and II in obesity. Endocrinology 145:1503-1513. CrossRef Medline

Jordan SD, Krüger M, Willmes DM, Redemann N, Wunderlich FT, Brönneke HS, Merkwirth C, Kashkar H, Olkkonen VM, Böttger T, Braun T, Seibler J, Brüning JC (2011) Obesity-induced overexpression of miRNA-143 inhibits insulin-stimulated AKT activation and impairs glucose metabolism. Nat Cell Biol 13:434-446. CrossRef Medline

Kaelin CB, Xu AW, Lu XY, Barsh GS (2004) Transcriptional regulation of 
agouti-related protein (Agrp) in transgenic mice. Endocrinology 145: 5798-5806. CrossRef Medline

Krüger M, Ruschke K, Braun T (2004) NSCL-1 and NSCL-2 synergistically determine the fate of GnRH-1 neurons and control necdin gene expression. EMBO J 23:4353-4364. CrossRef Medline

Lempp R (1957) Adiposogenital dystrophy and puberal obesity (in German). Z Mensch Vererb Konstitutionsl 34:289-302. Medline

Ley CJ, Lees B, Stevenson JC (1992) Sex- and menopause-associated changes in body-fat distribution. Am J Clin Nutr 55:950-954. Medline

Li C, Chen P, Smith MS (1999) Morphological evidence for direct interaction between arcuate nucleus neuropeptide Y (NPY) neurons and gonadotropin-releasing hormone neurons and the possible involvement of NPY Y1 receptors. Endocrinology 140:5382-5390. CrossRef Medline

Mattiasson I, Rendell M, Törnquist C, Jeppsson S, Hulthén UL (2002) Effects of estrogen replacement therapy on abdominal fat compartments as related to glucose and lipid metabolism in early postmenopausal women. Horm Metab Res 34:583-588. CrossRef Medline

Mayer C, Acosta-Martinez M, Dubois SL, Wolfe A, Radovick S, Boehm U, Levine JE (2010) Timing and completion of puberty in female mice depend on estrogen receptor alpha-signaling in kisspeptin neurons. Proc Natl Acad Sci U S A 107:22693-22698. CrossRef Medline

Ostberg JE, Thomas EL, Hamilton G, Attar MJ, Bell JD, Conway GS (2005) Excess visceral and hepatic adipose tissue in Turner syndrome determined by magnetic resonance imaging: estrogen deficiency associated with hepatic adipose content. J Clin Endocrinol Metab 90:2631-2635. CrossRef Medline

Parent AS, Teilmann G, Juul A, Skakkebaek NE, Toppari J, Bourguignon JP (2003) The timing of normal puberty and the age limits of sexual precocity: variations around the world, secular trends, and changes after migration. Endocr Rev 24:668-693. CrossRef Medline

Raposinho PD, Broqua P, Pierroz DD, Hayward A, Dumont Y, Quirion R, Junien JL, Aubert ML (1999) Evidence that the inhibition of luteinizing hormone secretion exerted by central administration of neuropeptide $\mathrm{Y}$ (NPY) in the rat is predominantly mediated by the NPY-Y5 receptor subtype. Endocrinology 140:4046-4055. CrossRef Medline

Roa J, García-Galiano D, Castellano JM, Gaytan F, Pinilla L, Tena-Sempere M (2010) Metabolic control of puberty onset: new players, new mechanisms. Mol Cell Endocrinol 324:87-94. CrossRef Medline
Sarfati J, Guiochon-Mantel A, Rondard P, Arnulf I, Garcia-Piñero A, Wolczynski S, Brailly-Tabard S, Bidet M, Ramos-Arroyo M, Mathieu M, Lienhardt-Roussie A, Morgan G, Turki Z, Bremont C, Lespinasse J, Du Boullay H, Chabbert-Buffet N, Jacquemont S, Reach G, De Talence N, et al. (2010) A comparative phenotypic study of kallmann syndrome patients carrying monoallelic and biallelic mutations in the prokineticin 2 or prokineticin receptor 2 genes. J Clin Endocrinol Metab 95:659-669. CrossRef Medline

Schwenk F, Baron U, Rajewsky K (1995) A cre-transgenic mouse strain for the ubiquitous deletion of loxP-flanked gene segments including deletion in germ cells. Nucleic Acids Res 23:5080-5081. CrossRef Medline

Sisk CL, Foster DL (2004) The neural basis of puberty and adolescence. Nat Neurosci 7:1040-1047. CrossRef Medline

Sotonyi P, Mezei G, Racz B, Dallman MF, Abizaid A, Horvath TL (2010) Gonadotropin-releasing hormone fibers contact POMC neurons in the hypothalamic arcuate nucleus. Reprod Sci 17:1024-1028. CrossRef Medline

van den Top M, Lee K, Whyment AD, Blanks AM, Spanswick D (2004) Orexigen-sensitive NPY/AgRP pacemaker neurons in the hypothalamic arcuate nucleus. Nat Neurosci 7:493-494. CrossRef Medline

Vella KR, Burnside AS, Brennan KM, Good DJ (2007) Expression of the hypothalamic transcription factor Nhlh2 is dependent on energy availability. J Neuroendocrinol 19:499-510. CrossRef Medline

Wankhade UD, Good DJ (2011) Melanocortin 4 receptor is a transcriptional target of nescient helix-loop-helix-2. Mol Cell Endocrinol 341:3947. CrossRef Medline

Yaswen L, Diehl N, Brennan MB, Hochgeschwender U (1999) Obesity in the mouse model of pro-opiomelanocortin deficiency responds to peripheral melanocortin. Nat Med 5:1066-1070. CrossRef Medline

Yepuru M, Eswaraka J, Kearbey JD, Barrett CM, Raghow S, Veverka KA, Miller DD, Dalton JT, Narayanan R (2010) Estrogen receptor- $\beta$ selective ligands alleviate high-fat diet- and ovariectomy-induced obesity in mice. J Biol Chem 285:31292-31303. CrossRef Medline

Yoon H, Enquist LW, Dulac C (2005) Olfactory inputs to hypothalamic neurons controlling reproduction and fertility. Cell 123:669-682. CrossRef Medline 